\title{
चUSGS
}

science for a changing world

\section{DENSITY AND VELOCITY RELATIONSHIPS}

FOR DIGITAL SONIC AND DENSITY LOGS

FROM COASTAL WASHINGTON AND

LABORATORY MEASUREMENTS OF OLYMPIC

PENINSULA MAFIC ROCKS AND GREYWACKES

by Thomas M. Brocher ${ }^{1}$ and Nikolas I. Christensen ${ }^{2}$

Open-File Report 01-264

US GEOLOGICAL SURVEY

OCT 152001

2001

nLUIUי, VA

This report is preliminary and has not been reviewed for conformity with U.S. Geological Survey editorial standards or with the North American Stratigraphic Code. Any use of trade, firm, or product names is for descriptive purposes only and does not imply endorsement by the U.S.

Government.

U.S. DEPARTMENT OF THE INTERIOR

U.S. GEOLOGICAL SURVEY

${ }_{1}^{1}$ U.S. Geological Survey, 345 Middlefield Road, M/S 977, Menlo Park, CA 94025

2 Dept. of Geology and Geophysics, 1215 W. Dayton St., University of Wisconsin, Madison, WI 53706 


\begin{abstract}
Three-dimensional velocity models for the basins along the coast of Washington and in Puget Lowland provide a means for better understanding the lateral variations in strong ground motions recorded there. We have compiled 16 sonic and 18 density logs from 22 oil test wells to help us determine the geometry and physical properties of the Cenozoic basins along coastal Washington. The depth ranges sampled by the test well logs fall between 0.3 and $2.1 \mathrm{~km}$. These well logs sample Quaternary to middle Eocene sedimentary rocks of the Quinault Formation, Montesano Formation, and Hoh rock assemblage. Most (18 or 82\%) of the wells are from Grays Harbor County, many of these are from the Ocean City area. These Grays Harbor County wells sample the Quinault Formation, Montesano Formation, and frequently bottom in the Hoh rock assemblage. These wells show that the sonic velocity and density normally increase significantly across the contacts between the Quinault or the Montesano Formations and the Hoh rock assemblage. Reflection coefficients calculated for vertically traveling compressional waves from the average velocities and densities for these units suggest that the top of the Hoh rock assemblage is a strong reflector of downward propagating seismic waves: these reflection coefficients lie between 11 and $20 \%$. Thus this boundary may reflect seismic energy upward and trap a substantial portion of the seismic energy generated by future earthquakes within the Miocene and younger sedimentary basins found along the Washington coast.

Three wells from Jefferson County provide data for the Hoh rock assemblage for the entire length of the logs. One well (Eastern Petroleum Sniffer Forks \#1), from the Forks area in Clallam County, also exclusively samples the Hoh rock assemblage. This report presents the locations, elevations, depths, stratigraphic and other information for all the oil test wells, and provides plots showing the density and sonic velocities as a function of depth for each well $\log$. We also present two-way travel times for 15 of the wells calculated from the sonic velocities. Average velocities and densities for the wells having both logs can be reasonably well related using a modified Gardner's rule, with $\rho=1825 \mathrm{v}^{1 / 4}$, where $\rho$ is density in $\mathrm{kg} / \mathrm{m}^{3}$ and $\mathrm{v}$ is the sonic velocity in $\mathrm{km} / \mathrm{s}$. In contrast, a similar analysis of published well logs from Puget Lowland is best matched by a Gardner's rule of $\rho=1730 \mathrm{v}^{1 / 4}$, close to the $\rho=1740 \mathrm{v}^{1 / 4}$ proposed by Gardner et al. (1974).

Finally, we present laboratory measurements of compressional-wave velocity, shearwave velocity, and density for 11 greywackes and 29 mafic rocks from the Olympic Peninsula and Puget Lowland. These units have significance for earthquake hazard investigations in Puget Lowland as they dip eastward beneath the Lowland, forming the "bedrock" beneath much of the lowland. Average $\mathrm{Vp} / \mathrm{Vs}$ ratios for the mafic rocks, mainly Crescent Formation volcanics, lie between 1.81 and 1.86. Average $\mathrm{Vp} / \mathrm{Vs}$ ratios for the greywackes from the accretionary core complex in the Olympic Peninsula show greater scatter but lie between 1.77 and 1.88 . Both the Olympic Peninsula mafic rocks and greywackes have lower shear-wave velocities than would be expected for a Poisson solid $\left(\mathrm{Vp} / \mathrm{Vs}_{\mathrm{s}}=1.732\right)$. Although the P-wave velocities and densities in the greywackes can be related by a Gardner's rule of $\rho=1720 \mathrm{v}^{1 / 4}$, close to the $\rho=1740 \mathrm{v}^{1 / 4}$ proposed by Gardner et al. (1974), the velocities and densities of the mafic rocks are best related by a Gardner's rule of $\rho=1840 \mathrm{v}^{1 / 4}$. Thus, the density/velocity relations are similar for the Puget Lowland well logs and greywackes from the Olympic Peninsula. Density/velocity relations are similar for the Washington coastal well logs and mafic rocks from the Olympic Peninsula, but differ from those of the Puget Lowland well logs and greywackes from the Olympic Peninsula.
\end{abstract}




\section{CONTENTS}

Abstract

Introduction

Well Log Analysis

Borehole Lithologies

Comments on the Well Log Data

Travel Time Curves

Laboratory Measurements

Density and Velocity Relationships

Earthquake Hazard Implications

Data Availability

Acknowledgments

References

\section{TABLE}

Table 1. Oil test well location and logging history

Table 2. Stratigraphy in the oil test wells

Table 3. Linear regression of the sonic velocity logs

Table 4. Linear regression of the density logs

Table 5. Compressional-wave measurements of Olympic Peninsula mafic rocks

Table 6. Shear-wave measurements of Olympic Peninsula mafic rocks

Table $7 . \mathrm{Vp} / \mathrm{Vs}$ ratios of Olympic Peninsula mafic rocks

Table 8. Poisson's ratio of Olympic Peninsula mafic rocks

Table 9. Compressional-wave measurements of Olympic Peninsula greywackes

Table 10. Shear-wave measurements of Olympic Peninsula greywackes

Table 11. Vp/Vs ratios of Olympic Peninsula greywackes

Table 12. Poisson's ratio of Olympic Peninsula greywackes

Table 13. Average Formation sonic velocities and densities

Table 14. Compressional-wave reflection coefficients

\section{FIGURES}

Figure 1. Map showing locations of oil test wells analyzed within this report

Figure 2. Sonic velocities and densities for Shell Oil OCA Hogan 1-13 and Shell Oil Hogan 1-8 wells

Figure 3. Sonic velocities and densities for Shell Oil Grays Harbor County OCA 1-11 and Ocean City Land Development Co. 1-14 wells

Figure 4. Sonic velocities and densities for Shell Oil John Sampson 1-15 and Shell Oil Johns Sampson 2-15, and El Paso Prod., Grays Harbor County 27-1 wells

Figure 5. Sonic velocities and densities for Shell Oil Luse 23 and Minard OCA 1-34 wells

Figure 6. Sonic velocities and densities for Shell Oil Grays Harbor County LHA 1-15 and Trambitas OCA 1-28 wells

Figure 7. Sonic velocities and densities for Shell Oil Grays Harbor County 1-35 and El Paso Production Grays Harbor County 36-1 wells

Figure 8. Sonic velocities and densities for Development Assoc., M A Baker 1-30, Development Assoc., Carlisle 1-23, and Humble Oil and Refining Everett Trust and Savings Bank ETR et al. B-1 wells 
Figure 9. Sonic velocities and densities for Humble Oil and Refining Ollar State 1 and Shell Oil McCleave 1-33 wells

Figure 10. Sonic velocities and densities for and Hoh River Oil Co. Barlow 1 El Paso Prod. Lacey No. 22-1, and Belco Petroleum Corp., Milwaukee Land 1-1 wells

Figure 11. Densities for Eastern Petroleum Services Sniffer Forks 1 well

Figure 12. Calculated two-way travel time for Shell Oil Hogan 1-13, Hogan 1-8, Grays Harbor County 1-11, and for Ocean City LD C 1-14 wells

Figure 13. Calculated two-way travel time for Shell Oil John Sampson 1-15, Johns Sampson OCA 2-15, Luse 1-23, and Minard OCA 1-34 wells

Figure 14. Calculated two-way travel time for Shell Oil Grays Harbor County LHA 1-15, Shell Oil Trambitas OCA 1-28, Shell Oil Grays Harbor County 1-35, Humble Oil and Refining Ollar State 1

Figure 15. Calculated two-way travel time for Humble Oil and Refining State ETR et al B-1, Shell Oil McCleave 1-33, Hoh River Oil Co. Barlow 1

Figure 16. Map of the Olympic Peninsula showing the location of rock samples measured in the laboratory

Figure 17. Compressional-wave, shear-wave, Vp/Vs ratio, and Poisson's ratio versus confining pressure for Olympic Peninsula mafic rocks (mainly Crescent Formation volcanics)

Figure 18. Compressional-wave, shear-wave, Vp/Vs ratio, and Poisson's ratio versus confining pressure for Olympic Peninsula

Figure 19. Average sonic velocities and densities for the well logs and laboratory measurements compiled by this study and those of Brocher and Ruebel (1998)

Figure 20. RMS misfit of Gardner's coefficient for the four rock suites investigated here and by Brocher and Ruebel (1998) 


\section{INTRODUCTION}

We present data from 16 sonic and 18 density logs from 22 oil test wells to categorize the sonic velocities and densities of Cenozoic sedimentary basins in coastal Washington (Fig. 1).

We also present laboratory measurements of compressional-wave and shear-wave velocities for 40 basement rocks outcropping in the Olympic Peninsula and Puget Lowland. These measurements were made on twenty-nine mafic rocks (mainly Crescent Formation volcanics) and eleven greywackes at room temperatures and confining pressures up to $1000 \mathrm{MPa}$ (10 Kbar). These measurements represent the first laboratory measurements of the shear-wave velocities for these important bedrock units.

We use these well log and laboratory measurements to examine velocity-density relationships for rock suites found in coastal Washington, the Olympic Peninsula, and Puget Lowland. For two of the suites of rocks investigated here, we note significant departures of these measurements from the density/velocity relationship proposed for sedimentary rocks by Gardner et al. (1974).

Finally, we use the average velocity and densities determined for sedimentary units in coastal Washington (the Quinault and Montesano Formations and the Hoh rock assemblage) to obtain estimates of the average seismic reflection coefficients in the sedimentary basins found along the coast of Washington. These estimates suggest that seismic waves might be efficiently trapped in the basins during future large earthquakes in the Pacific Northwest, enhancing the ground motions for the basins relative to nearby bedrock sites.

\section{WELL LOG ANALYSIS}

We first report the new sonic and density logs for the 22 oil test wells along coastal Washington. The locations, elevations, and depths of the wells, as well as the operator, lease name, well number, and completion year are presented in Table 1: the wells in this table are ordered by latitude from south to north. The well information in Table 1 is taken from the Well History Control System (WHCS) One-line File, an on-line digital well-log database leased from Petroleum Information by the USGS Office of Energy Resources at Denver. Table 1 provides information on the type of sonic and density tool used to make the log, as well as the other tools which were run simultaneously with these tools (normally caliper, spontaneous potential, and gamma-ray). Only a few of the sonic logs were made with older, short tools, with short spans between the source and receivers. Stratigraphic control is available for 21 of the 22 wells [Rau and McFarland, 1982; Palmer and Lingley, 1989].

Sonic and density logs were hand digitized at non-uniform intervals between 0.3 and 30 $m$ to capture the significant variations of the logs with depth for frequencies up to $20 \mathrm{~Hz}$. The average sampling interval was 1 to $3 \mathrm{~m}$. The sampling interval was adequate to estimate linear trends in the data over these intervals. We note that our sampling interval was not intended and is not sufficiently dense for the calculation of high-frequency (say $>50 \mathrm{~Hz}$ ) synthetic seismograms. For higher-frequency synthetics, it will be necessary to redigitize the logs with a finer sampling interval.

For the sonic logs, we picked transit times $(\mu \mathrm{s} / \mathrm{ft})$ as a function of depth down the well. For the gamma-gamma density logs, we picked bulk density in $\mathrm{kg} / \mathrm{m}^{3}$ as a function of depth down the well. For the neutron density porosity logs, we converted the logged density porosity $(\phi)$ to formation density $\left(\rho_{\mathrm{fd}}\right)$ using $\rho_{\mathrm{fd}}=\rho_{\mathrm{m}}+\left(\rho_{\mathrm{f}}-\rho_{\mathrm{m}}\right) \phi$, where the matrix density $\rho_{\mathrm{m}}=2650$ $\mathrm{kg} / \mathrm{m}^{3}$, and the fluid density $\rho_{\mathrm{f}}=1000 \mathrm{~kg} / \mathrm{m}^{3}$ [Ellis, 1987]. All of the logs analyzed here are plotted at a scale of $30.49 \mathrm{~m}: 5.08 \mathrm{~cm}$ (100 feet: 2.5 inches) or $30.49 \mathrm{~m}: 2.54 \mathrm{~cm}$ (100 feet: 1 inch). Depths are measured from an arbitrary reference datum, normally the Kelley Bushing (KB), located $3.65 \mathrm{~m}$ (12 feet) above ground level. The downhole depths reported here have not been corrected for this small upward shift. Cased intervals of the wells and sections identified on the logs as having cycle skipping problems were not digitized. In some cases data from the logs were ignored: these data were associated with washouts, thick mudcake, invasion of drill fluids 
or large deviations from the general trend of density and sonic values having very limited depth extent, generally less than a few meters [Ellis, 1987]. The digitized sonic log data were converted from transit times to velocities $(\mathrm{m} / \mathrm{s})$ and depths from feet to meters for both the sonic and density logs. Plots are presented in Figures 2 to 11 showing seismic velocities and densities as a function of depth for each well.

We have calculated two-way travel times from the sonic logs and displayed these in Figures 12 to 15 . This calculation required us to extrapolate sonic velocities to the surface. In one case, Belco Petroleum Corp. Milwaukee Land 1-1, the depth to the first measured sonic velocity was judged to be too great to extrapolate the sonic velocity to the surface.

\section{BOREHOLE LITHOLOGIES}

The following discussion of the borehole lithologies (Table 2) is summarized from Rau and McFarland (1982) and Palmer and Lingley (1989), who described the lithologies in the wells reported here. The reader is referred to these references for a more detailed discussion of the units sampled in the boreholes.

\section{Hoh rock assemblage}

The Hoh rock assemblage is composed of middle Eocene to middle Miocene, deep-water marine rocks thought to have been accreted to North America during the subduction process. Many of these rocks are turbidites and are mainly greywacke clastic sedimentary rocks. In the Forks area, most of the Hoh rock assemblage consists of thick sequences of siltstone, claystone, and sandstone. Alternations of these lithologies may explain the undulations observed in sonic and density logs of this formation.

\section{Quinault and Montesano Formations}

The Quinault Formation rests unconformably on the Hoh rock assemblage. Rau and McFarland (1982) discuss the uncertainty in the age of this unit, which includes late Miocene and Pliocene members. Rau and McFarland (1982) use the Quinault Formation for the sedimentary rocks of this age lying unconformably on the Hoh rock assemblage. Bergen and Bird (1972) and Palmer and Lingley (1989) believe most of these rocks to be late Miocene in age and refer to them as the Montesano Formation. Palmer and Lingley (1989) group rocks above the Montesano Formation and call them undifferentiated Quaternary deposits and Quinault Formation. For four of the Ocean City wells studied here we show the Montesano Formation as described by Palmer and Lingley (1989); for the remainder of the 22 wells we follow the formation identification provided by Rau and McFarland (1982).

From top to bottom the Montesano Formation contains a thick siltstone, sandstone, and claystone member. Similarly, the Quinault Formation identified by Rau and McFarland (1982) has claystone, sandstone, and siltstone members, which have fairly distinctive signatures in the sonic and density logs.

\section{Quaternary Deposits}

Few, if any, of the well logs sample Quaternary deposits, which are inferred to overlie the sampled units. The Shell John's 1-15 and Shell Sampson Johns OCA 2-15 wells may sample Quaternary deposits at the tops of the logs, but the available formation identifications are not definitive (Table 2). 


\section{COMMENTS ON THE WELL LOG DATA}

We superimposed the formation tops from Table 2 onto the well logs shown in this report. Often these formation contacts correspond to significant changes in the sonic velocity and density, and/or in the character of these logs.

In Table 3 we show average velocities and linear regressions over intervals corresponding to known or inferred formations. Similar averages and linear regressions on the density log data are shown in Table 4. As anticipated, average sonic velocities (generally 1400 to $2000 \mathrm{~m} / \mathrm{s}$ ) and densities $\left(2000 \mathrm{~kg} / \mathrm{m}^{3}\right)$ in the Quaternary deposits are significantly lower than those of underlying Tertiary sedimentary rocks (Tables 3 and 4). The contact between the Hoh rock assemblage and overlying Tertiary sedimentary rocks represents a large (about $0.3 \mathrm{~km} / \mathrm{s}$ ) increase in sonic velocity (Table 3).

\section{Hoh rock assemblage}

Long sections of the Hoh rock assemblage were logged at three wells near Joe Creek in Greys Harbor County as well as at four northernmost wells analyzed in this study (Figures 1, 10, and 11). In the Joe Creek area (Figure 1; T20N, R12W), the well logs show a substantial decrease in density and sonic velocity at a depth of about $1000 \mathrm{~m}(3280 \mathrm{ft})$. The logs for the four northernmost wells in Jefferson and Clallam Counties (Figure 10) show more minor variations with depth, particularly with respect to the density. The high scatter in sonic velocities in the Belco Petroleum Milwaukee Land 1-1 well (Figure 10) are due to cyclic skipping. Density logs for the El Paso Lacey No. 22-1 and Belco Petroleum Milwaukee Land 1-1 wells show a welldefined increase in density with depth (Figure 10).

\section{Quinault and Montesano Formations}

The Quinault Formation is characterized by low sonic velocities and densities. Sonic velocities generally lie between 2 and $2.5 \mathrm{~km} / \mathrm{s}$; densities generally lie between 2100 and 2300 $\mathrm{kg} / \mathrm{m}^{3}$. In many of the wells there is a distinctive unit within the Quinault Formation that is typified by rapid fluctuations in sonic velocity and density. This unit contains pebbles in a sandstone matrix. The rapid fluctuations in the logs are caused by sampling the higher sonic velocities and densities of the pebbles versus the lower-velocity and lower density matrix. This conglomeratic unit is especially well developed in Shell OCA Hogan \#1-13 (Figure 2), but is also seen in the Shell Hogan \#1-8 (Fig. 2), Shell Grays Harbor Co. OCA \#1-11 (Fig. 3), Shell Ocean City Land Development Co. \#1-14 (Fig. 3), Shell Sampson Johns OCA \#2-15 (in the Montesano Formation) (Fig. 4), Shell Luse \#1-23 (Fig. 5), and Shell Grays Harbor Co. \#1-35 (Fig. 7) wells.

Within the Quinault and Montesano Formations, the claystone member generally has the lowest velocities and densities and the sandstone member generally has the highest velocities and densities. The low densities and sonic velocities of the claystone member of the Quinault Formation are well displayed at the Shell Ocean City Land Development Co. \#1-14 well (Figure 3). The higher seismic velocities and densities of the sandstone member are typified by the Shell John's \#1-15 and Shell Sampson Johns OCA \#2-15 wells (Figure 4).

\section{Quaternary Deposits}

Only the Shell John's 1-15 and Shell Sampson Johns OCA 2-15 wells may sample Quaternary deposits at the tops of the logs (Figure 4). In these wells undifferentiated Quaternary deposits and Quinault Formation have velocities between 1.5 and $2.0 \mathrm{~km} / \mathrm{s}$ (Figure 4). The higher velocities in the John's \#1-15 well at about $300 \mathrm{~m}$ depth correspond to a pebbly sandstone 
member, most likely of the Quinault Formation (Rau and McFarland, 1982). No density logs were made for these intervals.

\section{TRAVEL TIME CURVES}

Individual travel time curves calculated for the wells having sonic well logs are shown in Figures 12 to 15. The calculated travel time curves are summarized in Figure 15. For the majority of the wells the curves plot closely together and nearly intersect the 1 second mark at a depth of $1000 \mathrm{~m}$, consistent with an average velocity of $2 \mathrm{~km} / \mathrm{s}$ to this depth. One curve, for the Shell-Minard 1-34 well, yields consistently larger travel times, consistent with its lower velocity (Figure 15). Both the travel time curve and sonic velocities are anomalous at the Shell-Minard 1-34 relative to nearby sites. The sonic log at Shell-Minard 1-34 was not compensated, and it may be possible that the sonic velocities measured there are systematically too low. [An alternative explanation is that the interval transit time scale was incorrectly read for this well.]

In contrast to these wells in Grays Harbor County, the travel time curves calculated for the Hoh River Barlow No. 1 (Figure 15) and Humble Oil Ollar State No. 1 (Figure 14) wells yield smaller travel times at all depths sampled. These smaller travel times are consistent with the higher sonic velocities found in the wells associated with the Hoh rock assemblage.

\section{LABORATORY MEASUREMENTS}

Laboratory determined velocities for 40 basement rocks outcropping in the Olympic Peninsula and Puget Lowland provide the first measurements of shear wave velocities for the Crescent Formation volcanics and greywackes in the Olympic accretionary core complex (Figure 16). Brocher et al. [2001] showed the compressional-wave velocity as a function of confining pressure for these rocks, but did not present the shear-wave velocity information, nor did they describe the variability of the measurements (summarized by Tables 5 to 12).

The eleven greywackes were taken from the accretionary wedge of the Olympic core complex; the 29 mafic samples are mainly basalts from the Crescent Formation (Figure 16). Mafic samples OL-10 and OL-15 represent gabbros within the Crescent Formation; the other mafic samples are basalts. Samples were field oriented by their bedding and flow structure. Velocities were measured in a hydrostatic pressure apparatus at room temperature using a pulse transmission technique described by Christensen [1985]. The laboratory data in Tables 5-12 and Figures 17 and 18 are uncorrected for increasing temperature in the crust, which can significantly lower the velocities in the lower crust (corrections are approximately -0.02 to $-0.06 \mathrm{~km} / \mathrm{s}$ per $100^{\circ} \mathrm{C}$ increase in temperature [Christensen, 1979]). Mean P-wave velocities for the two different rock suites at almost all confining pressures differ by at least $1 \mathrm{~km} / \mathrm{s}$ : even the standard deviations of the velocities for the two suites are distinct (Figures 17 and 18). Mean S-wave velocities for the mafic rocks and greywackes differ less significantly. We have also plotted $\mathrm{Vp} / \mathrm{Vs}$ and Poisson's ration as a function of confining pressure for the two rock suites.

The $\mathrm{Vp} / \mathrm{Vs}$ ratio for both the Olympic mafic rocks and greywackes are higher than average than would be expected for a Poisson solid $(\mathrm{Vp} / \mathrm{Vs}=1.732)$. Thus, the shear wave velocities expected for these lithologies are lower than might be predicted from their P-wave velocity assuming a Poisson's ratio of 0.25 . The $\mathrm{Vp} / \mathrm{V}$ s ratio shows relatively little sensitivity to confining pressure for the mafic rocks, but increases more significantly for the greywackes.

\section{DENSITY AND VELOCITY RELATIONSHIP}

Gardner et al. (1974) proposed an empirical relationship, based on borehole measurements, between sonic velocity and density in sedimentary rocks. The rule proposed by Gardner et al. (1974) is $\rho=1740 v^{1 / 4}$, where $\rho$ is density in $\mathrm{kg} / \mathrm{m}^{3}$ and $v$ is the sonic velocity in 
$\mathrm{km} / \mathrm{s}$. For the purpose of discussion, we will refer to the coefficient multiplying the factor of $\mathrm{v}^{1 / 4}$ as Gardner's coefficient.

In Figure 19 we plot average compressional-wave velocities and densities for the laboratory measurements of Olympic Peninsula greywackes and mafic rocks at $100 \mathrm{MPa}$ (Tables 5 and 9), for the wells in Coastal Washington reported here, and in Puget Lowland as reported by Brocher and Ruebel (1998) are plotted in Figure 19. We determined the Gardner's coefficient for each suite of rocks by minimizing the misfit between the observed and calculated density (Figure 20). For each suite of rocks the Gardner's coefficient was determined from a welldefined minima in the root-mean-square (RMS) curves of misfit versus Gardner's coefficient (Figure 20).

P-wave velocities and densities of the Olympic Peninsula greywackes and well log data sampling sedimentary rocks in the Puget Lowland (Brocher and Ruebel, 1998) are best fit by Gardner's coefficients of 1720 and 1730, respectively (Figure 20). These values are very close to the coefficient of 1740 proposed for sedimentary rocks by Gardner et al. (1974).

In contrast, the velocities and densities for the Washington Coast wells and Olympic Peninsula mafic rocks are best fit by much higher Gardner's coefficients of 1835 and 1840 , respectively (Figures 19 and 20). These coefficients are significantly higher than the value of 1740 determined by Gardner et al. (1974) for sedimentary rocks.

Figure 20 demonstrates that there are significant differences between the Olympic Peninsula greywackes and mafic rocks and between the Puget Lowland and the Coastal Washington sedimentary rocks measured in the sonic and density logs.

To what can we ascribe the high Gardner's coefficient needed for the sedimentary rocks sampled in the coastal Washington well logs? Figure 20 suggests that the high Gardner's coefficient required for the coastal Washington wells may result from the inclusion of Olympic mafic rocks within the Quinault and Montesano Formations and in the Hoh rock assemblage.

\section{EARTHQUAKE HAZARDS IMPLICATIONS}

The low sonic velocities and densities within the Quinault and Montesano Formations and the abrupt increase of these parameters in the underlying Hoh rock assemblage suggest that strong ground motions along the coast will be amplified due to the presence of these formations.

Reflection coefficients calculated for vertically traveling compressional waves were calculated from

$$
\operatorname{Rpp}=\left(v_{2} \rho_{2}-v_{1} \rho_{1}\right) /\left(v_{2} \rho_{2}+v_{1} \rho_{1}\right)
$$

where $v$ is the sonic velocity and $\rho$ is the density, and 1 represents the upper layer and 2 the bottom layer.

Reflection coefficients (Table 14) calculated from the average velocities and densities for these units (Table 13) suggest that the top of the Hoh rock assemblage is a strong reflector of downward propagating seismic waves: these reflection coefficients lie between 11 and $20 \%$. The magnitudes of these coefficients are all consistent with strong seismic reflectors. Thus this boundary may reflect upwards and trap a substantial portion of the seismic energy generated by future earthquakes within the Miocene and younger sedimentary basins found along the Washington coast. The largest reflection coefficients (20\%) would be expected for the case when Quaternary deposits directly overlie the Hoh rock assemblage.

Although we have calculated compressional-wave reflection coefficients, we believe that these are appropriate for shear-waves as well. If the $\mathrm{Vp} / \mathrm{Vs}$ ratio is constant for these rocks, then Rss should be identical to Rpp. If $\mathrm{Vp} / \mathrm{Vs}$ increases with formation age and/or depth, then Rss would be higher than the Rpp calculated here. 


\section{DATA AVAILABILITY}

The densities, seismic velocities, and two-way travel times shown in Figures 2 to 15 and Tables 5 to 12 are available in Excel5 spreadsheets using anonymous ftp (swave.wr.usgs.gov at /pub/outgoing/brocher)

\section{ACKNOWLEDGEMENTS}

Zenon Valin, USGS, kindly performed a search of a digital database providing well locations and other well information. Larry Beyer, USGS, made many useful suggestions for digitizing the well log data. Rick Blakely, USGS, reviewed an earlier version of this report. Pat McCrory provided a copy of Figure 1, modified here.

This work was supported by the National Earthquake Hazards Reduction Program.

\section{REFERENCES CITED}

Bergen, F.W., and Bird, K.J., 1972, The biostratigraphy of the Ocean City area, Washington: Proceedings of the Pacific Coast Miocene Biostratigraphic Symposium: presented at the $47^{\text {th }}$ Annual Pacific Section S.E.P.M. convention, March 9-10, 1972, Bakersfield, California, p. 173-191.

Brocher, T.M. and Ruebel, A.L., 1998, Compilation of 29 sonic and density logs from 23 oil test wells in western Washington State, U.S. Geological Survey Open-File Report 98-249, 41 p.

Brocher, T.M., T. Parsons, R.A. Blakely, N.I. Christensen, M.A. Fisher, R.E. Wells, and the SHIPS Working Group, 2001, Upper crustal structure in Puget Lowland, Washington: Results from 1998 Seismic Hazards Investigation in Puget Sound, J. Geophy. Res., 106, $13,541-13,564$.

Christensen, N.I., 1979, Compressional wave velocities in rocks at high temperature and pressures, critical thermal gradients and crustal low-velocity zones, J. Geophys. Res., 84, 6849-6857.

Christensen, N.I., 1985, Measurements of dynamic properties of rock at elevated pressures and temperatures, in Measurements of Rock Properties at Elevated Pressures and Temperatures, edited by H. J. Pincus and E. R. Hoskins, pp. 93-107, American Society for Testing and Materials, Philadelphia, Pa.

Ellis, D.V., 1987, Well Logging for Earth Scientists, Elsevier, New York, 532 p.

Gardner, G.H.F., L.W. Gardner, and A.R. Gregory, 1974, Formation velocity and density; the diagnostic basics for stratigraphic traps, Geophysics, 39, 770-780.

Johnson, S.Y.,Tennyson, M.E., Lingley, W.S., and Law, B.E., 1993, Petroleum geology of the State of Washington: U.S. Geological Survey, Professional Paper 1582, 40 pp.

McFarland, C.R., 1983, Oil and gas exploration in Washington, 1900-1982, Washington (State), Dept. of Natural Resources, Div. Geology and Earth Resources, Information Circular 75, $119 \mathrm{p}$.

Palmer, S.P., and W.S. Lingley, 1989, An assessment of the oil and gas potential of the Washington outer continental shelf, Washington State \& Offshore Oil and Gas, Washington Sea Grant Program, Univ. of Wash., Seattle, 83 p., 12 plates.

Rau, W.W., and McFarland, C.R., 1982, Coastal wells of Washington: Washington Division of Geology and Earth Resources Report of Investigations 26, 4 plates. 
Table 1. Oil test well location and logging history.

\begin{tabular}{|c|c|c|c|c|c|c|c|c|c|c|c|c|c|c|c|c|c|}
\hline Operator & Leasename & No. & County & Latitude & Longitude & $\frac{\text { Depth }}{(\mathrm{ft})}$ & $\frac{\text { Depth }}{(\mathrm{m})}$ & $I$ & & $\underline{\mathrm{R}}$ & $\underline{\mathrm{S}}$ & $\frac{\text { Elev. }}{(\mathrm{ft})}$ & $\frac{\text { Elev. }}{(\mathrm{m})}$ & Year & $\underline{\text { Sonic Log }}$ & $\begin{array}{l}\text { Density } \\
\text { Log }\end{array}$ & Other Logs \\
\hline Shell Oil & Shell-Minard & $1-34$ & Grays Harbor & 47.01294 & -124.15234 & 4600 & 1402 & $18 N$ & $\mathrm{~N}$ & $12 \mathrm{~W}$ & 34 & 27 & 8 & 1970 & T3R & CFD gg & Cal., GR, SP \\
\hline Shell Oil & Luse & $1-23$ & Grays Harbor & 47.04164 & -124.14824 & 3602 & 1098 & $18 N$ & N & $12 W$ & 23 & 8 & 2 & 1970 & BHC T3R2R & CFD gg & Cal., GR, SP \\
\hline Shell Oil & Sampson Johns & $2-15$ & Grays Harbor & 47.04555 & $-124,16222$ & 2390 & 729 & $18 N$ & $\mathrm{~N}$ & $12 W$ & 15 & 13 & 4 & 1970 & BHC T3R2R & & Cal., SP \\
\hline Shell Oil & Shell-Sampson J & $1-15$ & Grays Harbor & 47.04732 & -124.15396 & 2795 & 852 & $18 N$ & $\mathrm{~N}$ & $12 W$ & 15 & 20 & 6 & 1970 & BHC T3R2R & CFD gg & Cal., GR \\
\hline Shell Oil & Ocean City LD C & $1-14$ & Grays Harbor & 47.04738 & -124.13805 & 4268 & 1301 & $18 N$ & N & $12 W$ & 14 & 30 & 9 & 1970 & BHC T3R2R & CFD gg & Cal., GR, SP \\
\hline Shell Oil & Hogan & $1-13$ & Grays Harbor & 47.05186 & -124.12610 & 2922 & 891 & $18 N$ & $\mathrm{~N}$ & $12 W$ & 13 & 45 & 14 & 1970 & BHC T3R2R & CFD gg & Cal., SP \\
\hline Shell Oil & Hogan & $1-8$ & Grays Harbor & 47.05762 & -124.07370 & 1395 & 425 & $18 N$ & N & $11 \mathrm{~W}$ & 8 & 35 & 11 & 1970 & BHC T3R2R & CFD gg & Cal., GR, SP \\
\hline Shell Oil & $\begin{array}{r}\text { Grays Harbor } \\
\text { County }\end{array}$ & $1-11$ & Grays Harbor & 47.06535 & -124.13080 & 3240 & 988 & $18 N$ & $\mathrm{~N}$ & $12 W$ & 11 & 20 & 6 & 1970 & BHC T3R2R & CNFD & Cal., GR, SP \\
\hline Shell Oil & $\begin{array}{r}\text { Grays Harbor } \\
\text { County }\end{array}$ & $1-35$ & Grays Harbor & 47.09222 & -124.14999 & 2527 & 770 & $19 N$ & N & $12 \mathrm{~W}$ & 35 & 60 & 18 & 1970 & BHC T3R2R & CFD gg & Cal., GR, SP \\
\hline El Paso Product. & $\begin{array}{l}\text { Grays Harbor } \\
\text { Community }\end{array}$ & $27-1$ & Grays Harbor & 47.09741 & -123.78906 & 4600 & 1402 & $19 N$ & N & $9 \mathrm{~W}$ & 27 & 411 & 125 & 1975 & & CFD gg & Cal., GR \\
\hline El Paso Product. & $\begin{array}{r}\text { Grays Harbor } \\
\text { County }\end{array}$ & $36-1$ & Grays Harbor & 47.09778 & -124.12517 & 2769 & 844 & $19 N$ & N & $12 \mathrm{~W}$ & 36 & 65 & 20 & 1974 & & CFD gg & Cal., GR \\
\hline Shell Oil & Shell Trambites & $1-28$ & Grays & 47. & 53 & 3111 & 948 & $19 N$ & $\mathrm{~N}$ & $12 W$ & 28 & 12 & 4 & 1970 & BHC T3R2R & CFD gg & Cal., GR, SP \\
\hline Shell Oil & $\begin{array}{r}\text { Grays Harbor } \\
\text { County LHA }\end{array}$ & $1-15$ & Grays Harbor & 47.13101 & -124.15640 & 2032 & 620 & $19 N$ & N & $12 W$ & 15 & 45 & 14 & 1970 & BHC T3R2R & CFD gg & Cal., GR, SP \\
\hline Shell & Shell-McCleave & $1-33$ & s Harbor & 47.1 & 867 & 1344 & 410 & 201 & $\mathrm{~N}$ & $12 \mathrm{~W}$ & 33 & 132 & 40 & 1970 & T3R2R & CFD gg & Cal., GR, SP \\
\hline $\begin{array}{l}\text { Development } \\
\text { Assoc. }\end{array}$ & M A Baker & $1-30$ & Grays Harbor & 47.19826 & -124.10410 & 4000 & 1220 & $20 N$ & N & $11 \mathrm{~W}$ & 30 & 460 & 140 & 1973 & & $\begin{array}{l}\text { Sidewall } \\
\text { NFD }\end{array}$ & Cal., GR \\
\hline $\begin{array}{l}\text { Humble Oil \& } \\
\text { Ref. }\end{array}$ & Ollar State & 1 & Grays Harbor & 47.20285 & -124.12630 & 5000 & 1524 & $20 N$ & N & $12 \mathrm{~W}$ & 24 & 450 & 137 & 1961 & T3R1R & & Cal., SP \\
\hline $\begin{array}{l}\text { Humble Oil \& } \\
\text { Ref. }\end{array}$ & $\begin{array}{r}\text { Everett Trust } \\
\text { and Savings }\end{array}$ & B-1 & Grays Harbor & 47.20285 & -124.12630 & 5000 & 1524 & 201 & N & $12 \mathrm{~W}$ & 24 & 450 & 137 & 1961 & T3R1R & & Cal. \\
\hline $\begin{array}{l}\text { Development } \\
\text { Assoc. }\end{array}$ & Carlisle & $1-23$ & Grays Harbor & 47.20645 & -124.13293 & 4100 & 1250 & 201 & $\mathrm{~N}$ & $12 \mathrm{~W}$ & 23 & 284 & 87 & 1974 & & $\begin{array}{l}\text { CFD gg, } \\
\text { CNFD }\end{array}$ & Cal., GR \\
\hline Hoh River Oil Co. & Barlow & 1 & Jeffers & 47.74931 & -124.40286 & 5015 & 1529 & $25 N$ & N & $12 W$ & 20 & 20 & 6 & 1965 & T3R3R? & & Cal., SP \\
\hline El Paso Product. & Lacey & $22-1$ & Jeffer & 47.74689 & 36052 & 5700 & 1738 & $26 N$ & N & $13 \mathrm{~W}$ & 22 & 261 & 80 & 1974 & & CFD gg & Cal., GR \\
\hline Belco Petr. Corp. & Milwaukee Land & $1-1$ & Jefferson & 47.88261 & -124.43869 & 6880 & 2098 & $27 N$ & N & $14 \mathrm{~W}$ & 1 & 140 & 43 & 1966 & BHC T3R2R & CFD gg & Cal., GR, SP \\
\hline $\begin{array}{c}\text { Eastern Petr. } \\
\text { Serv. }\end{array}$ & Sniffer Forks & 1 & Clallam & 47.93750 & -124.38028 & 3095 & 944 & $28 N$ & N & $13 \mathrm{~W}$ & 16 & 533 & 163 & 1973 & & CFD gg & Cal., GR \\
\hline
\end{tabular}

BHC - Borehole Compensated Sonic Log

CFD gg - Compensated Formation Density (gamma-gamma)*

SP - Spontaneous Potential

T3R3R - Sonic tool spacing (in feet) between transmitter (T) and receivers (R)
CNFD - Compensated Neutron Formation Density*

Cal. - Caliper

GR - Gamma Ray

*All density logging tools employ the backscattered gamma-ray technique, commonly called "gamma-gamma". The different names used here are either from different vendors or from different generations (having different trademark names). 
Table 2. Stratigraphy in oil test wells

\begin{tabular}{|c|c|c|c|}
\hline Well Name & Formation & Depth (ft) & Depth $(\mathrm{m})$ \\
\hline \multirow[t]{3}{*}{ Shell Hogan No. 1-8 } & Quaternary deposits & $0-800 ?$ & $0-244 ?$ \\
\hline & Quinault (?) Fm. & $450-1300$ & $137-396$ \\
\hline & Hoh rock assemblage (?) & 1300-TD & 396-TD \\
\hline \multirow[t]{2}{*}{ Shell Hogan No. 1-13 } & No data & $0-503$ & $0-153$ \\
\hline & Quinault Fm. & 503-TD & $153-\mathrm{TD}$ \\
\hline \multirow[t]{3}{*}{ Shell Grays Harbor Co. No. 1-11 } & Quaternary (?) sediments & $0-300$ & $0-92$ \\
\hline & Quinault Fm. & $300-2850$ & $92-869$ \\
\hline & Hoh rock assemblage & 2850-TD & 869-TD \\
\hline \multirow[t]{3}{*}{ Shell Ocean City Land Co. No. 1-14 } & No data & $0-919$ & $0-280$ \\
\hline & Quinault Fm. & $919-3690$ & $280-1125$ \\
\hline & Hoh rock assemblage & 3690-TD & $1125-\mathrm{TD}$ \\
\hline \multirow[t]{3}{*}{ Shell Sampson Johns No. 1-15 } & $\begin{array}{l}\text { Undiff. Quat. Deposits and Quinault } \\
\text { Fm. }\end{array}$ & $0-1150$ & $0-351$ \\
\hline & Montesano Fm. - siltstone member & $1150-1935$ & $351-590$ \\
\hline & Montesano Fm. - sandstone member & $1935-2650$ & $590-808$ \\
\hline \multirow[t]{3}{*}{ Shell Sampson Johns No. 2-15 } & $\begin{array}{l}\text { Undiff. Quat. Deposits and Quinault } \\
\text { Fm. }\end{array}$ & $0-925$ & $0-282$ \\
\hline & Montesano Fm. - siltstone member & $925-1410$ & $282-430$ \\
\hline & Montesano Fm. - sandstone member & $1410-2125$ & $430-648$ \\
\hline \multirow[t]{4}{*}{ Shell Luse No. 1-23 } & $\begin{array}{l}\text { Undiff. Quat. Deposits and Quinault } \\
\text { Fm. }\end{array}$ & $0-1820$ & $0-555$ \\
\hline & Montesano Fm. - siltstone member & $1820-2650$ & $555-808$ \\
\hline & Montesano Fm. - sandstone member & $2650-2725$ & $808-831$ \\
\hline & Montesano Fm. - claystone member & 2725-TD & $831-\mathrm{TD}$ \\
\hline \multirow[t]{3}{*}{ Shell Minard No. 1-34 } & No data & $0-520$ & $0-159$ \\
\hline & Quinault Fm. & $520-4450$ & $159-1357$ \\
\hline & Hoh rock assemblage & 4450-TD & 1357-TD \\
\hline \multirow[t]{3}{*}{ Shell Grays Harbor LHA No. 1-15 } & No data & $0-500$ & $0-152$ \\
\hline & Quinault Fm. & $500-1800$ & $152-549$ \\
\hline & Hoh rock assemblage & $1800-\mathrm{TD}$ & 549-TD \\
\hline \multirow[t]{3}{*}{ Shell Trambitas No. 1-28 } & No data & $0-1000$ & $0-305$ \\
\hline & Quinault Fm. & $1000-2900$ & $305-892$ \\
\hline & Hoh rock assemblage & 2925-TD & 892-TD \\
\hline \multirow[t]{2}{*}{ Shell Grays Harbor Co. No. 1-35 } & Quinault Fm. & $0-2500$ & $0-762$ \\
\hline & Hoh rocks (?) & 2500-TD & $762-\mathrm{TD}$ \\
\hline \multirow[t]{3}{*}{ El Paso Grays Harbor Co. No. 36-1 } & No data & $0-514$ & $0-157$ \\
\hline & Quinault Fm. & $514-1740$ & $157-530$ \\
\hline & Hoh River assemblage & 1740-TD & 530-TD \\
\hline \multirow[t]{2}{*}{ Devel. Assoc. M A Baker No. 1-30 } & Post Miocene hiatus & $0-280$ & $0-85$ \\
\hline & Hoh rock assemblage & 280-TD & 85-TD \\
\hline \multirow[t]{2}{*}{ Devel. Assoc. Carlisle No. 1-23 } & Quaternary (?) sediments & $0-540$ & $0-165$ \\
\hline & Late Eocene & 540-TD & $165-\mathrm{TD}$ \\
\hline \multirow[t]{2}{*}{ Humble Ollar State No. 1} & Quaternary (?) sediments & $0-380$ & $0-116$ \\
\hline & Hoh rock assemblage & 380-TD & 116-TD \\
\hline \multirow{2}{*}{$\begin{array}{l}\text { Humble Everett Trust and Savings } \\
\text { Bank ETR et al. B-1 }\end{array}$} & Quaternary (?) sediments & & \\
\hline & Hoh rock assemblage? & 1210-TD & 369-TD \\
\hline \multirow[t]{3}{*}{ Shell McLeave No. 1-33 } & Quaternary sediments & $0-450$ & $0-137$ \\
\hline & Quinault Fm. & $450-1130$ & $137-345$ \\
\hline & Hoh rock assemblage & $1130-1344$ & $345-910$ \\
\hline Hoh River Oil Barlow No. 1 & Hoh rock assemblage & 0-TD & $0-T D$ \\
\hline \multirow{2}{*}{ El Paso Lacey No. 22-1 } & Quaternary deposits & $0-220$ & $0-67$ \\
\hline & Hoh rock assemblage & $220-\mathrm{TD}$ & 67-TD \\
\hline Belco Milwaukee Land No. 1-1 & Hoh rock assemblage & 615-TD & 188-TD \\
\hline Eastern Petrol. Sniffer Forks No. 1 & Hoh rock assemblage & $0-\mathrm{TD}$ & $0-\mathrm{TD}$ \\
\hline
\end{tabular}

Sources: Rau and McFarland (1982), Palmer and Lingley (1989) 
Table 3. Linear regression of sonic velocities in oil test well log

\begin{tabular}{|c|c|c|c|c|c|c|}
\hline Wellname and number & Formation Name & $\begin{array}{l}\text { Depth } \\
\text { Interval } \\
(\mathrm{m})\end{array}$ & $\begin{array}{l}\text { Average } \\
\text { Velocity } \\
(\mathrm{km} / \mathrm{s})\end{array}$ & $\begin{array}{l}\text { Intercept } \\
\text { Velocity } \\
(\mathrm{km} / \mathrm{s})\end{array}$ & $\begin{array}{l}\text { Velocity } \\
\text { Gradient } \\
(\mathrm{km} / \mathrm{s} / \mathrm{km})\end{array}$ & $\mathrm{R}^{2}$ \\
\hline \multirow[t]{2}{*}{ Shell Hogan No. 1-8 } & Quinault (?) Fm. & $137-396$ & 2.460 & & & \\
\hline & Hoh rock assemblage (?) & 396-TD & 2.105 & & & \\
\hline \multirow[t]{3}{*}{ Shell Hogan No. 1-13 } & $\begin{array}{l}\text { Quinault Fm. - pebbly } \\
\text { sand or sandstone }\end{array}$ & $153-625$ & 2.218 & & & \\
\hline & Quinault Fm. - siltstone & $625-793$ & 2.383 & & & \\
\hline & Quinault Fm. - claystone & $793-891$ & 2.097 & & & \\
\hline \multirow{2}{*}{$\begin{array}{l}\text { Shell Grays Harbor Co. No. } \\
\qquad 1-11\end{array}$} & $\begin{array}{l}\text { Quinault Fm. - sand and } \\
\text { conglomerate }\end{array}$ & $294-438$ & 2.218 & & & \\
\hline & $\begin{array}{c}\text { Quinault Fm. - claystone } \\
\text { Hoh rock assemblage }\end{array}$ & $\begin{array}{l}438-869 \\
869-\mathrm{TD}\end{array}$ & $\begin{array}{l}2.047 \\
2.035\end{array}$ & & & \\
\hline \multirow[t]{2}{*}{$\begin{array}{l}\text { Shell Ocean City Land Co. } \\
\text { No. 1-14 }\end{array}$} & $\begin{array}{l}\text { Quinault Fm. - sand and } \\
\text { conglomerate }\end{array}$ & $280-650$ & 2.292 & & & \\
\hline & Quinault Fm. - claystone & $\begin{array}{l}650-1125 \\
1125-\mathrm{TD}\end{array}$ & 1.969 & & & \\
\hline \multirow{4}{*}{$\begin{array}{l}\text { Shell Sampson Johns No. 1- } \\
\qquad 15\end{array}$} & $\begin{array}{l}\text { Undiff. Quat. Deposits } \\
\text { and Quinault Fm. }\end{array}$ & $133-351$ & 1.720 & & & \\
\hline & $\begin{array}{l}\text { Montesano Fm.- } \\
\text { siltstone member }\end{array}$ & $351-590$ & 2.018 & & & \\
\hline & $\begin{array}{l}\text { Montesano Fm.- } \\
\text { sandstone member }\end{array}$ & $590-808$ & 2.248 & & & \\
\hline & $\begin{array}{l}\text { Montesano Fm.- } \\
\text { claystone member }\end{array}$ & $808-852$ & 2.028 & & & \\
\hline \multirow{4}{*}{$\begin{array}{l}\text { Shell Sampson Johns No. 2- } \\
\quad 15\end{array}$} & $\begin{array}{l}\text { Undiff. Quat. Deposits } \\
\text { and Quinault Fm. }\end{array}$ & $0-282$ & 1.642 & & & \\
\hline & $\begin{array}{l}\text { Montesano Fm.-- } \\
\text { siltstone member }\end{array}$ & $282-430$ & 2.294 & & & \\
\hline & $\begin{array}{l}\text { Montesano Fm. - } \\
\text { sandstone member }\end{array}$ & $430-648$ & 2.629 & & & \\
\hline & $\begin{array}{l}\text { Montesano Fm.- } \\
\text { claystone member }\end{array}$ & 648-TD & 2.184 & & & \\
\hline \multirow[t]{4}{*}{ Shell Luse No. 1-23 } & $\begin{array}{l}\text { Undiff. Quat. Deposits } \\
\text { and Quinault Fm. }\end{array}$ & $263-555$ & 2.241 & & & \\
\hline & $\begin{array}{l}\text { Montesano Fm.- } \\
\text { siltstone member }\end{array}$ & $555-808$ & 2.366 & & & \\
\hline & $\begin{array}{l}\text { Montesano Fm. - } \\
\text { sandstone member }\end{array}$ & $808-831$ & 2.334 & & & \\
\hline & $\begin{array}{l}\text { Montesano Fm. - } \\
\text { claystone member }\end{array}$ & 831-TD & 2.147 & & & \\
\hline \multirow[t]{3}{*}{ Shell Minard OCA No. 1-34 } & $\begin{array}{l}\text { Quinault Fm. - sand and } \\
\text { gravel }\end{array}$ & $159-290$ & 1.584 & & & \\
\hline & $\begin{array}{l}\text { Quinault Fm. - } \\
\text { sandstone and silty } \\
\text { sandstone }\end{array}$ & $290-762$ & 1.775 & & & \\
\hline & $\begin{array}{l}\text { Quinault Fm. - claystone } \\
\text { Hoh rock assemblage }\end{array}$ & $\begin{array}{l}762-1357 \\
1357-\mathrm{TD}\end{array}$ & $\begin{array}{l}1.810 \\
2.243\end{array}$ & & & \\
\hline \multirow{2}{*}{$\begin{array}{l}\text { Shell Grays Harbor LHA } \\
\text { No. } 1-15\end{array}$} & Undiff. Plio-Pleistocene & $285-305$ & 1.978 & & & \\
\hline & $\begin{array}{l}\text { Quinault Fm. } \\
\text { Hoh rock assemblage }\end{array}$ & $\begin{array}{l}305-549 \\
549-\mathrm{TD}\end{array}$ & $\begin{array}{l}2.090 \\
3.339\end{array}$ & & & \\
\hline \multirow[t]{3}{*}{ Shell Trambitas No. 1-28 } & Quinault Fm. - sandstone & $347-488$ & 2.061 & & & \\
\hline & $\begin{array}{l}\text { Quinault Fm. - claystone } \\
\text { and siltstone }\end{array}$ & $488-892$ & 2.251 & & & \\
\hline & Hoh rock assemblage & 892-TD & 2.871 & & & \\
\hline \multirow{3}{*}{$\begin{array}{l}\text { Shell Grays Harbor Co. No. } \\
\qquad \begin{array}{l}-35\end{array}\end{array}$} & Quinault Fm. - sandstone & $316-518$ & 2.165 & & & \\
\hline & $\begin{array}{l}\text { Quinault Fm. - siltstone } \\
\text { with sandstone }\end{array}$ & $518-701$ & 2.246 & & & \\
\hline & $\begin{array}{c}\text { Quinault Fm. - claystone } \\
\text { Hoh rocks (?) }\end{array}$ & $\begin{array}{l}701-762 \\
762-\mathrm{TD}\end{array}$ & $\begin{array}{l}2.186 \\
2.480\end{array}$ & & & \\
\hline
\end{tabular}


Humble Ollar State No. 1

Humble Everett Trust and

Savings Bank ETR et al.

$$
\text { B-1 }
$$

Shell McLeave No. 1-33

Hoh River Oil Barlow No. 1

Belco Milwaukee Land No.
Hoh rock assemblage

Hoh rock assemblage

Quinault Fm.

Hoh rock assemblage

Hoh rock assemblage

Hoh rock assemblage
116-TD

369-TD

2.676

2.497

2.423

2.136

0.3551

0.479

0.0696
0.1609 1-1 $\begin{array}{ll}137-345 & 2.039\end{array}$

345-405 2.713

0 -TD $\quad 2.574$

188-TD $\quad 3.243$

$\begin{array}{lll}1.757 & 1.2909 & 0.5501 \\ 1.561 & 1.2319 & 0.2755\end{array}$


Table 4. Linear regression of densities in oil test well logs

\begin{tabular}{|c|c|c|c|c|c|c|}
\hline Wellname and number & Formation Name & $\begin{array}{l}\text { Depth } \\
\text { Interval } \\
(\mathrm{m})\end{array}$ & $\begin{array}{l}\text { Average } \\
\text { Density } \\
\left(\mathrm{kg} / \mathrm{m}^{3}\right)\end{array}$ & $\begin{array}{l}\text { Intercept } \\
\text { Density } \\
\left(\mathrm{kg} / \mathrm{m}^{3}\right)\end{array}$ & $\begin{array}{c}\text { Density } \\
\text { Gradient } \\
\left(\mathrm{kg} / \mathrm{m}^{3} / \mathrm{m}\right)\end{array}$ & $\mathrm{R}^{2}$ \\
\hline \multirow[t]{2}{*}{ Shell Hogan No. 1-8 } & $\begin{array}{l}\text { Quinault (?) Fm. - sand } \\
\text { and conglomerate }\end{array}$ & $286-396$ & 2335.1 & & & \\
\hline & $\begin{array}{c}\text { Hoh rock assemblage } \\
\text { (?) }\end{array}$ & 396-TD & 2167.1 & & & \\
\hline \multirow[t]{3}{*}{ Shell Hogan No. 1-13 } & $\begin{array}{l}\text { Quinault Fm. - pebbly } \\
\text { sand or sandstone }\end{array}$ & $153-625$ & 2271 & & & \\
\hline & Quinault Fm. - siltstone & $625-793$ & 2218.9 & & & \\
\hline & $\begin{array}{l}\text { Quinault Fm. - } \\
\text { claystone }\end{array}$ & $793-891$ & 2155.6 & & & \\
\hline \multirow[t]{3}{*}{$\begin{array}{l}\text { Shell Grays Harbor Co. No. } \\
\qquad 1-11\end{array}$} & $\begin{array}{l}\text { Quinault Fm. - } \\
\text { sandstone and } \\
\text { conglomerate }\end{array}$ & $294-438$ & 2270.3 & & & \\
\hline & $\begin{array}{l}\text { Quinault Fm. - } \\
\text { claystone }\end{array}$ & $438-869$ & 2162.8 & & & \\
\hline & Hoh rock assemblage & 869-TD & 2206.8 & & & \\
\hline \multirow[t]{2}{*}{$\begin{array}{l}\text { Shell Ocean City Land Co. } \\
\text { No. } 1-14\end{array}$} & $\begin{array}{l}\text { Quinault Fm. - } \\
\text { sandstone and } \\
\text { conglomerate }\end{array}$ & $280-650$ & 2297.8 & & & \\
\hline & $\begin{array}{l}\text { Quinault Fm. - } \\
\text { claystone }\end{array}$ & $650-1125$ & 2120.0 & & & \\
\hline \multirow[t]{3}{*}{$\begin{array}{l}\text { Shell Sampson Johns No. 1- } \\
\quad 15\end{array}$} & $\begin{array}{l}\text { Hoh rock assemblage } \\
\text { Montesano Fm.- } \\
\text { siltstone member }\end{array}$ & $\begin{array}{l}1125-\mathrm{TD} \\
381-590\end{array}$ & $\begin{array}{l}2345.6 \\
2155.9\end{array}$ & & & \\
\hline & $\begin{array}{l}\text { Montesano Fm.-- } \\
\text { sandstone member }\end{array}$ & $590-808$ & 2287.0 & & & \\
\hline & $\begin{array}{l}\text { Montesano Fm. - } \\
\text { claystone member }\end{array}$ & $808-852$ & 2240.6 & & & \\
\hline \multirow[t]{4}{*}{ Shell Luse No. 1-23 } & $\begin{array}{l}\text { Undiff. Quat. Deposits } \\
\text { and Ouinault Fm. }\end{array}$ & $231-555$ & 2242.4 & & & \\
\hline & $\begin{array}{l}\text { Montesano Fm.- } \\
\text { siltstone member }\end{array}$ & $555-808$ & 2108.3 & & & \\
\hline & $\begin{array}{l}\text { Montesano Fm.-- } \\
\text { sandstone member }\end{array}$ & $808-831$ & 2173.6 & & & \\
\hline & $\begin{array}{l}\text { Montesano Fm. - } \\
\text { claystone member }\end{array}$ & 831-TD & 2134.5 & & & \\
\hline \multirow[t]{4}{*}{ Shell Minard No. 1-34 } & $\begin{array}{c}\text { Quinault Fm. - sand } \\
\text { and gravel }\end{array}$ & $159-290$ & 2037.0 & & & \\
\hline & $\begin{array}{l}\text { Quinault Fm. - } \\
\text { sandstone and silty } \\
\text { sandstone }\end{array}$ & $290-762$ & 2182.0 & & & \\
\hline & $\begin{array}{l}\text { Quinault Fm. - } \\
\text { claystone }\end{array}$ & $762-1357$ & 2212.3 & & & \\
\hline & Hoh rock assemblage & 1357-TD & 2400.7 & & & \\
\hline \multirow[t]{2}{*}{$\begin{array}{l}\text { Shell Grays Harbor LHA } \\
\text { No. } 1-15\end{array}$} & $\begin{array}{l}\text { Quinault Fm. - Undiff. } \\
\text { Plio-Pleistocene }\end{array}$ & $158-305$ & 2103.4 & & & \\
\hline & Quinault Fm. & $305-549$ & 2185.9 & & & \\
\hline \multirow[t]{3}{*}{ Shell Trambitas No. 1-28 } & $\begin{array}{l}\text { Hoh rock assemblage } \\
\text { Quinault Fm. - } \\
\text { sandstone }\end{array}$ & $\begin{array}{l}549-\mathrm{TD} \\
305-488\end{array}$ & $\begin{array}{l}2528.9 \\
2167.2\end{array}$ & & & \\
\hline & $\begin{array}{l}\text { Quinault Fm.- } \\
\text { claystone and siltstone }\end{array}$ & $488-892$ & 2199.1 & & & \\
\hline & Hoh rock assemblage & 892-TD & 2478.1 & & & \\
\hline \multirow[t]{3}{*}{$\begin{array}{l}\text { Shell Grays Harbor Co. No. } \\
\qquad 1-35\end{array}$} & $\begin{array}{l}\text { Quinault Fm. - } \\
\text { sandstone }\end{array}$ & $316-518$ & 2188.4 & & & \\
\hline & $\begin{array}{l}\text { Quinault Fm. - } \\
\text { siltstone with sandstone }\end{array}$ & $518-701$ & 2226.7 & & & \\
\hline & $\begin{array}{l}\text { Quinault Fm. - } \\
\text { claystone }\end{array}$ & $701-762$ & 2183.3 & & & \\
\hline
\end{tabular}


El Paso Grays Harbor Co.

No. 36-1

El Paso Grays Harbor Co. No. 27-1

Devel. Assoc. M A Baker No. 1-30

Devel. Assoc. Carlisle No. 123

Shell McLeave No. 1-33

El Paso Lacey No. 22-1

Belco Milwaukee Land No. $1-1$

Eastern Petrol. Sniffer Forks No. 1
Hoh rocks (?) 762-TD 2401.0

Quinault Fm. $\quad 157-530 \quad 2145.2$

Hoh River assemblage 530-TD 2399.5

$\begin{array}{lll}\text { No data } & \text { No data } & 2193.6\end{array}$

85-TD 2335.

165-TD

2280.0

2424

$-0.2$

0.2987

Quinault Fm.

137-345 2120.0

$345-910 \quad 2453.0$

67-TD 2384.0

188-TD 2415.0

2313

2264

0.08

0.38

Hoh rock assemblage

0-TD

2345.0

2348

$-0.02$

0.0049

\author{
-TD
}


Table 5. Laboratory measurements of compressional-wave velocities in Olympic mafic rocks $\mathrm{Vp} \mathrm{km} / \mathrm{s}$ )

\begin{tabular}{|c|c|c|c|c|c|c|c|c|c|c|c|}
\hline \multirow[t]{2}{*}{ Sample } & \multirow{2}{*}{$\begin{array}{c}\text { Density } \\
\mathrm{kg} / \mathrm{m} 3\end{array}$} & \multicolumn{10}{|c|}{ Pressure (MPa) } \\
\hline & & 20 & 40 & 60 & 80 & 100 & 200 & 400 & 600 & 800 & 1000 \\
\hline OL-1 & 2831 & 4.65 & 4.85 & 4.99 & 5.09 & 5.17 & 5.40 & 5.59 & 5.68 & 5.74 & 5.79 \\
\hline OL-2 & 2871 & 5.21 & 5.40 & 5.52 & 5.60 & 5.66 & 5.82 & 5.95 & 6.02 & 6.07 & 6.11 \\
\hline OL-4 & 2935 & 6.15 & 6.29 & 6.37 & 6.43 & 6.47 & 6.58 & 6.67 & 6.72 & 6.75 & 6.78 \\
\hline OL-5 & 2800 & 5.73 & 5.87 & 5.96 & 6.04 & 6.09 & 6.24 & 6.33 & 6.36 & 6.38 & 6.39 \\
\hline OL-7 & 2852 & 4.87 & 5.33 & 5.55 & 5.68 & 5.75 & 5.90 & 6.03 & 6.11 & 6.17 & 6.21 \\
\hline OL-8 & 2841 & 5.03 & 5.30 & 5.46 & 5.57 & 5.64 & 5.85 & 6.04 & 6.15 & 6.23 & 6.29 \\
\hline OL-9 & 2861 & 5.43 & 5.57 & 5.68 & 5.75 & 5.82 & 6.01 & 6.16 & 6.21 & 6.25 & 6.28 \\
\hline OL-10 & 3046 & 6.59 & 6.66 & 6.69 & 6.72 & 6.74 & 6.81 & 6.88 & 6.93 & 6.96 & 6.99 \\
\hline OL-11 & 3026 & 6.45 & 6.51 & 6.54 & 6.57 & 6.59 & 6.66 & 6.73 & 6.78 & 6.81 & 6.84 \\
\hline OL-12 & 2943 & 6.13 & 6.20 & 6.23 & 6.26 & 6.28 & 6.35 & 6.44 & 6.50 & 6.54 & 6.57 \\
\hline OL-13 & 2959 & 6.08 & 6.18 & 6.23 & 6.26 & 6.29 & 6.39 & 6.52 & 6.60 & 6.66 & 6.70 \\
\hline-14 & 21 & 5.04 & 5.23 & 5.34 & 5,42 & 5.49 & 5.69 & 5,89 & 6.02 & 6.10 & 6.17 \\
\hline OL-15 & 2952 & 6.62 & 6.68 & 6.72 & 6.75 & 6.77 & 6.84 & 6.90 & 6.94 & 6.97 & 6.99 \\
\hline OL-16 & 2759 & 6.01 & 6.04 & 6.06 & 6.08 & 6.10 & 6.16 & 6.24 & 6.30 & 6.34 & 6.37 \\
\hline $\mathrm{OL}-17$ & 2949 & 6.23 & 6.29 & 6.33 & 6.35 & 6.37 & 6.46 & 6.56 & 6.63 & 6.68 & 6.71 \\
\hline OL-18 & 2918 & 5.88 & 5.94 & 5.98 & 6.01 & 6.04 & 6.13 & 6.25 & 6.33 & 6.39 & 6.43 \\
\hline OL-19 & 2977 & 6.26 & 6.36 & 6.42 & 6.46 & 6.49 & 6.61 & 6.73 & 6.81 & 6.86 & 6.91 \\
\hline-20 & 386 & 5.81 & 5.89 & 5.93 & 5.96 & 5.99 & 6.09 & 6.20 & 6.27 & 6.32 & 6.36 \\
\hline OL-21 & 366 & 6.26 & 6.33 & 6.37 & 6.41 & 6.44 & 6.53 & 6.61 & 6.65 & 6.68 & 6.69 \\
\hline OL-22 & 2914 & 6.05 & 6.13 & 6.17 & 6.20 & 6.22 & 6.31 & 6.42 & 6.49 & 6.54 & 6.57 \\
\hline OL-23 & 2947 & 5.90 & 5.99 & 6.04 & 6.08 & 6.11 & 6.22 & 6.34 & 6.42 & 6.47 & 6.52 \\
\hline OL-24 & 2694 & 5.76 & 5.80 & 5.84 & 5.86 & 5.88 & 5.94 & 6.00 & 6.02 & 6.04 & 6.05 \\
\hline OL-25 & 2872 & 5.98 & 6.03 & 6.05 & 6.07 & 6.08 & 6.13 & 6.20 & 6.25 & 6.28 & 6.31 \\
\hline OL-26 & 2834 & 6.06 & 6.14 & 6.18 & 6.22 & 6.24 & 6.33 & 6.44 & 6.51 & 6.56 & 6.59 \\
\hline OL-27 & 2951 & 5.83 & 5.92 & 5.98 & 6.02 & 6.05 & 6.17 & 6.32 & 6.41 & 6.47 & 6.52 \\
\hline OL-28 & 2922 & 5.58 & 5.69 & 5.75 & 5.80 & 5.84 & 5.96 & 6.10 & 6.19 & 6.25 & 6.30 \\
\hline 20 & 2692 & 5.09 & 5.15 & 5.20 & 5.24 & 5.27 & 5.39 & 5.52 & 5.59 & 5.64 & 5.66 \\
\hline OL-30 & 2899 & 5.78 & 5.83 & 5.87 & 5.90 & 5.93 & 6.02 & 6.14 & 6.22 & 6.28 & 6.33 \\
\hline OL-31 & 2999 & 6.19 & 6.24 & 6.27 & 6.29 & 6.31 & 6.35 & 6.38 & 6.40 & 6.42 & 6.43 \\
\hline Aver. & 2890 & 5.81 & 5.92 & 5.99 & 6.04 & 6.07 & 6.18 & 6.30 & 6.36 & 6.41 & 6.44 \\
\hline
\end{tabular}

Table 6. Laboratory measurements of shear-wave velocity in Olympic mafic rocks

\begin{tabular}{|c|c|c|c|c|c|c|c|c|c|c|c|}
\hline \multicolumn{12}{|c|}{ Vs $(\mathrm{km} / \mathrm{s})$} \\
\hline \multirow[t]{2}{*}{ Sample } & \multirow{2}{*}{$\begin{array}{c}\text { Density } \\
\mathrm{kg} / \mathrm{m} 3\end{array}$} & \multicolumn{10}{|c|}{ Pressure (MPa) } \\
\hline & & 20 & 40 & 60 & 80 & 100 & 200 & 400 & 600 & 800 & 1000 \\
\hline $\mathrm{OL}-1$ & 2831 & 2.85 & 2.95 & 3.02 & 3.06 & 3.09 & 3.17 & 3.23 & 3.27 & 3.30 & 3.32 \\
\hline $\mathrm{OL}-2$ & 2871 & 2.94 & 3.04 & 3.10 & 3.14 & 3.17 & 3.25 & 3.29 & 3.31 & 3.33 & 3.34 \\
\hline $\mathrm{OL}-4$ & 2935 & 3.22 & 3.33 & 3.41 & 3.46 & 3.49 & 3.58 & 3.62 & 3.64 & 3.65 & 3.66 \\
\hline OL-5 & 2800 & 3.28 & 3.35 & 3.39 & 3.43 & 3.45 & 3.50 & 3.53 & 3.54 & 3.54 & 3.55 \\
\hline $\mathrm{OL}-7$ & 2852 & 2.93 & 3.02 & 3.08 & 3.11 & 3.14 & 3.21 & 3.27 & 3.31 & 3.33 & 3.35 \\
\hline OL-8 & 2841 & 3.01 & 3.06 & 3.10 & 3.12 & 3.14 & 3.20 & 3.26 & 3.30 & 3.33 & 3.35 \\
\hline OL-9 & 2861 & 3.07 & 3.13 & 3.16 & 3.18 & 3.20 & 3.26 & 3,33 & 3.36 & 3.39 & 3.41 \\
\hline OL-10 & 3046 & 3.64 & 3.66 & 3.67 & 3.68 & 3.69 & 3.71 & 3.74 & 3.76 & 3.77 & 3.78 \\
\hline OL-11 & 3026 & 3.52 & 3.54 & 3.55 & 3.56 & 3.57 & 3.59 & 3.62 & 3.64 & 3.65 & 3.66 \\
\hline OL- 12 & 2943 & 3.65 & 3.39 & 3.40 & 3.41 & 3.42 & 3.45 & 3.48 & 3.51 & 3.53 & 3.54 \\
\hline OL-13 & 2959 & 3.36 & 3.39 & 3.40 & 3.41 & 3.42 & 3.47 & 3.52 & 3.56 & 3.58 & 3.60 \\
\hline OL- 14 & 2821 & 2.55 & 2.63 & 2.69 & 2.72 & 2.75 & 2.86 & 2.99 & 3.08 & 3.15 & 3.21 \\
\hline OL- 15 & 2952 & 3.59 & 3.62 & 3.63 & 3.64 & 3.65 & 3.68 & 3.70 & 3.71 & 3.72 & 3.73 \\
\hline OL-16 & 2759 & 3.08 & 3.10 & 3.11 & 3.12 & 3.12 & 3.15 & 3.17 & 3.18 & 3.19 & 3.20 \\
\hline OL- 17 & 2949 & 3.34 & 3.38 & 3.39 & 3.41 & 3.42 & 3.45 & 3.49 & 3.52 & 3.54 & 3.55 \\
\hline OL-18 & 2918 & 3.25 & 3.28 & 3.29 & 3.30 & 3.31 & 3.35 & 3.39 & 3.42 & 3.44 & 3.45 \\
\hline OL-19 & 2977 & 3.37 & 3.40 & 3.42 & 3.44 & 3.45 & 3.50 & 3.54 & 3.57 & 3.58 & 3.60 \\
\hline OL-20 & 2886 & 3.21 & 3.24 & 3.26 & 3.27 & 3.28 & 3.31 & 3.34 & 3.36 & 3.37 & 3.38 \\
\hline OL-21 & 2866 & 3.42 & 3.46 & 3.47 & 3.49 & 3.50 & 3.54 & 3.58 & 3.61 & 3.63 & 3.65 \\
\hline OL-22 & 2914 & 3.29 & 3.32 & 3.34 & 3.35 & 3.36 & 3.39 & 3.45 & 3.49 & 3.51 & 3.53 \\
\hline $\mathrm{OL}-23$ & 2947 & 3.29 & 3.32 & 3.34 & 3.35 & 3.36 & 3.40 & 3.44 & 3.47 & 3.49 & 3.50 \\
\hline OL-24 & 2694 & 3.05 & 3.07 & 3.09 & 3.10 & 3.11 & 3.13 & 3.15 & 3.16 & 3.17 & 3.17 \\
\hline OL-25 & 2872 & 3.23 & 3.26 & 3.27 & 3.28 & 3.29 & 3.32 & 3.35 & 3.37 & 3.38 & 3.39 \\
\hline OL-26 & 2834 & 3.22 & 3.26 & 3.28 & 3.30 & 3.31 & 3.36 & 3.41 & 3.44 & 3.46 & 3.48 \\
\hline
\end{tabular}




\begin{tabular}{rlllllllllll} 
OL-27 & 2951 & 3.21 & 3.26 & 3.29 & 3.31 & 3.33 & 3.38 & 3.45 & 3.49 & 3.52 & 3.54 \\
OL-28 & 2922 & 3.14 & 3.19 & 3.22 & 3.24 & 3.26 & 3.33 & 3.39 & 3.41 & 3.43 & 3.44 \\
OL-29 & 2692 & 2.67 & 2.72 & 2.75 & 2.77 & 2.79 & 2.86 & 2.91 & 2.93 & 2.95 & 2.96 \\
OL-30 & 2899 & 3.24 & 3.26 & 3.28 & 3.29 & 3.30 & 3.33 & 3.39 & 3.42 & 3.44 & 3.46 \\
OL-31 & 2999 & 3.38 & 3.46 & 3.50 & 3.52 & 3.53 & 3.55 & 3.55 & 3.55 & 3.55 & 3.55 \\
Aver. & 2890 & 3.21 & 3.24 & 3.27 & 3.29 & 3.31 & 3.35 & 3.40 & 3.43 & 3.45 & 3.46 \\
\hline
\end{tabular}

Table 7. Laboratory derived $\mathrm{Vp} / \mathrm{Vs}$ ratios for Olympic mafic rocks.

\begin{tabular}{|c|c|c|c|c|c|c|c|c|c|c|c|}
\hline \multirow[t]{2}{*}{ Sample } & \multirow{2}{*}{$\begin{array}{c}\text { Density } \\
\mathrm{kg} / \mathrm{m} 3\end{array}$} & \multicolumn{10}{|c|}{ Pressure $(\mathrm{MPa})$} \\
\hline & & 20 & 40 & 60 & 80 & 100 & 200 & 400 & 600 & 800 & 1000 \\
\hline OL-1 & 2831 & 1.63 & 1.64 & 1.65 & 1.66 & 1.67 & 1.70 & 1.73 & 1.74 & 1.74 & 1.75 \\
\hline OL-2 & 2871 & 1.77 & 1.78 & 1.78 & 1.78 & 1.78 & 1.79 & 1.81 & 1.82 & 1.82 & 1.83 \\
\hline OL-4 & 2935 & 1.91 & 1.89 & 1.87 & 1.86 & 1.85 & 1.84 & 1.84 & 1.85 & 1.85 & 1.85 \\
\hline OL-5 & 2800 & 1.75 & 1.75 & 1.76 & 1.76 & 1.77 & 1.78 & 1.79 & 1.80 & 1.80 & 1.80 \\
\hline OL-7 & 2852 & 1.66 & 1.76 & 1.81 & 1.82 & 1.83 & 1.84 & 1.84 & 1.85 & 1.85 & 1.86 \\
\hline OL-8 & 2841 & 1.67 & 1.73 & 1.76 & 1.78 & 1.80 & 1.83 & 1.85 & 1.86 & 1.87 & 1.88 \\
\hline OL-9 & 2861 & 1.77 & 1.78 & 1.80 & 1.81 & 1.82 & 1.84 & 1.85 & 1.85 & 1.84 & 1.84 \\
\hline OL-10 & 3046 & 1.81 & 1.82 & 1.82 & 1.83 & 1.83 & 1.83 & 1.84 & 1.84 & 1.85 & 1.85 \\
\hline $\mathrm{OL}-11$ & 3026 & 1.83 & 1.84 & 1.84 & 1.84 & 1.85 & 1.85 & 1.86 & 1.86 & 1.86 & 1.87 \\
\hline $\mathrm{OL}-12$ & 2943 & 1.68 & 1.83 & 1.83 & 1.84 & 1.84 & 1.84 & 1.85 & 1.85 & 1.86 & 1.86 \\
\hline OL-13 & 2959 & 1.81 & 1.82 & 1.83 & 1.83 & 1.84 & 1.84 & 1.85 & 1.85 & 1.86 & 1.86 \\
\hline OL-14 & 2821 & 1.97 & 1.98 & 1.99 & 1.99 & 1.99 & 1.99 & 1.97 & 1.95 & 1.94 & 1.92 \\
\hline OL-15 & 2952 & 1.84 & 1.85 & 1.85 & 1.85 & 1.85 & 1.86 & 1.87 & 1.87 & 1.87 & 1.88 \\
\hline OL-16 & 2759 & 1.95 & 1.95 & 1.95 & 1.95 & 1.95 & 1.96 & 1.97 & 1.98 & 1.99 & 1.99 \\
\hline OL-17 & 2949 & 1.86 & 1.86 & 1.86 & 1.86 & 1.87 & 1.87 & 1.88 & 1.88 & 1.89 & 1.89 \\
\hline OL-18 & 2918 & 1.81 & 1.81 & 1.82 & 1.82 & 1.82 & 1.83 & 1.84 & 1.85 & 1.86 & 1.86 \\
\hline OL-19 & 2977 & 1.86 & 1.87 & 1.87 & 1.88 & 1.88 & 1.89 & 1.90 & 1.91 & 1.92 & 1.92 \\
\hline OL-20 & 2886 & 1.81 & 1.82 & 1.82 & 1.82 & 1.83 & 1.84 & 1.86 & 1.87 & 1.87 & 1.88 \\
\hline OL-21 & 2866 & 1.83 & 1.83 & 1.84 & 1.84 & 1.84 & 1.85 & 1.85 & 1.84 & 1.84 & 1.84 \\
\hline OL-22 & 2914 & 1.84 & 1.84 & 1.85 & 1.85 & 1.85 & 1.86 & 1.86 & 1.86 & 1.86 & 1.86 \\
\hline OL-23 & 2947 & 1.79 & 1.80 & 1.81 & 1.81 & 1.82 & 1.83 & 1.84 & 1.85 & 1.86 & 1.86 \\
\hline OL-24 & 2694 & 1.89 & 1.89 & 1.89 & 1.89 & 1.89 & 1.90 & 1.90 & 1.91 & 1.91 & 1.91 \\
\hline OL-25 & 2872 & 1.85 & 1.85 & 1.85 & 1.85 & 1.85 & 1.85 & 1.85 & 1.86 & 1.86 & 1.86 \\
\hline OL-26 & 2834 & 1.88 & 1.88 & 1.88 & 1.88 & 1.88 & 1.88 & 1.89 & 1.89 & 1.89 & 1.90 \\
\hline OL-27 & 2951 & 1.82 & 1.82 & 1.82 & 1.82 & 1.82 & 1.82 & 1.83 & 1.84 & 1.84 & 1.84 \\
\hline OL-28 & 2922 & 1.78 & 1.78 & 1.79 & 1.79 & 1.79 & 1.79 & 1.80 & 1.81 & 1.82 & 1.83 \\
\hline OL-29 & 2692 & 1.91 & 1.90 & 1.89 & 1.89 & 1.89 & 1.89 & 1.90 & 1.91 & 1.91 & 1.91 \\
\hline OL-30 & 2899 & 1.78 & 1.79 & 1.79 & 1.79 & 1.80 & 1.81 & 1.81 & 1.82 & 1.83 & 1.83 \\
\hline OL-31 & 2999 & 1.83 & 1.80 & 1.79 & 1.79 & 1.79 & 1.79 & 1.80 & 1.80 & 1.81 & 1.81 \\
\hline Aver. & 2890 & 1.81 & 1.83 & 1.83 & 1.83 & 1.84 & 1.84 & 1.85 & 1.86 & 1.86 & 1.86 \\
\hline
\end{tabular}

Table 8. Laboratory derived Poisson's ratio for Olympic mafic rocks

$(\sigma)$

\begin{tabular}{cccccccccccc}
\hline Sample & Density & \multicolumn{1}{c}{ Pressure (MPa) } \\
& $\mathrm{kg} / \mathrm{m} 3$ & 20 & 40 & 60 & 80 & 100 & 200 & 400 & 600 & 800 & 1000 \\
\hline OL-1 & 2831 & 0.199 & 0.206 & 0.212 & 0.217 & 0.222 & 0.237 & 0.248 & 0.252 & 0.255 & 0.256 \\
OL-2 & 2871 & 0.267 & 0.269 & 0.270 & 0.271 & 0.271 & 0.274 & 0.279 & 0.282 & 0.285 & 0.287 \\
OL-4 & 2935 & 0.310 & 0.304 & 0.300 & 0.297 & 0.294 & 0.290 & 0.291 & 0.292 & 0.293 & 0.294 \\
OL-5 & 2800 & 0.257 & 0.259 & 0.261 & 0.263 & 0.265 & 0.270 & 0.275 & 0.276 & 0.277 & 0.278 \\
OL-7 & 2852 & 0.216 & 0.263 & 0.279 & 0.285 & 0.287 & 0.289 & 0.292 & 0.293 & 0.295 & 0.296 \\
OL-8 & 2841 & 0.222 & 0.249 & 0.263 & 0.271 & 0.276 & 0.287 & 0.294 & 0.297 & 0.300 & 0.302 \\
OL-9 & 2861 & 0.265 & 0.271 & 0.276 & 0.279 & 0.283 & 0.291 & 0.294 & 0.293 & 0.292 & 0.291 \\
OL-10 & 3046 & 0.282 & 0.284 & 0.285 & 0.285 & 0.286 & 0.288 & 0.290 & 0.291 & 0.292 & 0.293 \\
OL-11 & 3026 & 0.288 & 0.290 & 0.291 & 0.292 & 0.292 & 0.295 & 0.297 & 0.298 & 0.298 & 0.299 \\
OL-12 & 2943 & 0.226 & 0.287 & 0.288 & 0.289 & 0.290 & 0.291 & 0.293 & 0.294 & 0.295 & 0.296 \\
OL-13 & 2959 & 0.281 & 0.285 & 0.287 & 0.289 & 0.290 & 0.292 & 0.293 & 0.295 & 0.296 & 0.297 \\
OL-14 & 2821 & 0.327 & 0.330 & 0.331 & 0.332 & 0.332 & 0.331 & 0.327 & 0.322 & 0.318 & 0.314 \\
OL-15 & 2952 & 0.292 & 0.293 & 0.294 & 0.294 & 0.295 & 0.296 & 0.298 & 0.300 & 0.301 & 0.302 \\
OL-16 & 2759 & 0.322 & 0.322 & 0.322 & 0.322 & 0.322 & 0.323 & 0.327 & 0.329 & 0.330 & 0.331
\end{tabular}




\begin{tabular}{llllllllllll} 
OL-17 & 2949 & 0.297 & 0.298 & 0.298 & 0.298 & 0.298 & 0.300 & 0.302 & 0.304 & 0.305 & 0.306 \\
OL-18 & 2918 & 0.280 & 0.281 & 0.282 & 0.283 & 0.284 & 0.287 & 0.291 & 0.294 & 0.296 & 0.297 \\
OL-19 & 2977 & 0.297 & 0.300 & 0.301 & 0.302 & 0.303 & 0.305 & 0.308 & 0.311 & 0.313 & 0.314 \\
OL-20 & 2886 & 0.280 & 0.282 & 0.284 & 0.284 & 0.285 & 0.290 & 0.295 & 0.299 & 0.301 & 0.303 \\
OL-21 & 2866 & 0.286 & 0.287 & 0.289 & 0.290 & 0.291 & 0.293 & 0.292 & 0.291 & 0.290 & 0.289 \\
OL-22 & 2914 & 0.290 & 0.292 & 0.293 & 0.294 & 0.295 & 0.297 & 0.297 & 0.297 & 0.297 & 0.297 \\
OL-23 & 2947 & 0.275 & 0.278 & 0.280 & 0.281 & 0.282 & 0.287 & 0.291 & 0.294 & 0.296 & 0.297 \\
OL-24 & 2694 & 0.305 & 0.305 & 0.306 & 0.306 & 0.306 & 0.308 & 0.309 & 0.310 & 0.310 & 0.310 \\
OL-25 & 2872 & 0.294 & 0.294 & 0.293 & 0.293 & 0.293 & 0.292 & 0.294 & 0.295 & 0.296 & 0.297 \\
OL-26 & 2834 & 0.303 & 0.304 & 0.304 & 0.304 & 0.304 & 0.304 & 0.305 & 0.306 & 0.307 & 0.307 \\
OL-27 & 2951 & 0.282 & 0.282 & 0.283 & 0.283 & 0.284 & 0.285 & 0.287 & 0.289 & 0.290 & 0.291 \\
OL-28 & 2922 & 0.268 & 0.271 & 0.272 & 0.272 & 0.272 & 0.274 & 0.278 & 0.282 & 0.285 & 0.288 \\
OL-29 & 2692 & 0.310 & 0.308 & 0.306 & 0.306 & 0.305 & 0.305 & 0.308 & 0.310 & 0.312 & 0.312 \\
OL-30 & 2899 & 0.271 & 0.272 & 0.274 & 0.275 & 0.276 & 0.279 & 0.282 & 0.284 & 0.286 & 0.287 \\
OL-31 & 2999 & 0.287 & 0.278 & 0.274 & 0.272 & 0.272 & 0.273 & 0.276 & 0.278 & 0.280 & 0.280 \\
Aver & 2890 & 0.279 & 0.284 & 0.286 & 0.287 & 0.288 & 0.291 & 0.294 & 0.295 & 0.296 & 0.297 \\
\hline
\end{tabular}

Table 9. Laboratory measurements of compressional wave velocity of Olympic greywackes

\begin{tabular}{|c|c|c|c|c|c|c|c|c|c|c|c|}
\hline \multicolumn{12}{|c|}{$\mathrm{Vp}(\mathrm{km} / \mathrm{s})$} \\
\hline \multirow[t]{2}{*}{ Sample } & \multirow{2}{*}{$\begin{array}{c}\text { Density } \\
\mathrm{kg} / \mathrm{m} 3\end{array}$} & \multicolumn{10}{|c|}{ Pressure (MPa) } \\
\hline & & 20 & 40 & 60 & 80 & 100 & 200 & 400 & 600 & 800 & 1000 \\
\hline OLG-1 & 2480 & 4.03 & 4.10 & 4.15 & 4.18 & 4.20 & & & & & \\
\hline OLG-2 & 2440 & 4.04 & 4.18 & 4.27 & 4.34 & 4.39 & 4.60 & 4.86 & 5.03 & & \\
\hline OLG-3 & 2340 & 4.62 & 4.76 & 4.84 & 4.91 & 4.96 & 5.16 & 5.40 & 5.56 & & \\
\hline OLG-5 & 2640 & 5.41 & 5.50 & 5.57 & 5.61 & 5.65 & 5.79 & 5.94 & 6.02 & & \\
\hline OLG-6 & 2660 & 5.30 & 5.33 & 5.36 & 5.38 & 5.39 & & & & & \\
\hline OLG-7 & 2630 & 5.21 & 5.29 & 5.34 & 5.38 & 5.41 & 5.53 & 5.69 & 5.80 & & \\
\hline OLG-8 & 2610 & 4.98 & 5.00 & 5.02 & 5.04 & 5.06 & 5.15 & 5.34 & 5.53 & & \\
\hline OLG-9 & 2520 & 3.77 & 3.90 & 3.99 & 4.05 & 4.11 & 4.31 & 4.57 & 4.76 & & \\
\hline OLG-10 & 2580 & 4.84 & 4.96 & 5.06 & 5.14 & 5.20 & & & & & \\
\hline OLG-11 & 2410 & 4.15 & 4.21 & 4.29 & 4.33 & 4.37 & 4.61 & 4.88 & 5.07 & & \\
\hline OLG- 12 & 2843 & 4.47 & 4.89 & 5.18 & 5.39 & 5.55 & 5.93 & 6.14 & 6.24 & 6.31 & 6.36 \\
\hline Aver. & 2559 & 4.62 & 4.74 & 4.82 & 4.89 & 4.94 & 5.13 & 5.35 & 5.50 & 6.31 & 6.36 \\
\hline
\end{tabular}

Table 10. Laboratory measurements of shear wave velocity of Olympic greywackes

\begin{tabular}{|c|c|c|c|c|c|c|c|c|c|c|c|}
\hline \multicolumn{12}{|c|}{$\mathrm{Vs}(\mathrm{km} / \mathrm{s})$} \\
\hline \multirow[t]{2}{*}{ Sample } & Density & \multicolumn{10}{|c|}{ Pressure $(\mathrm{MPa})$} \\
\hline & $\mathrm{kg} / \mathrm{m} 3$ & 20 & 40 & 60 & 80 & 100 & 200 & 400 & 600 & 800 & 1000 \\
\hline OLG-1 & 2480 & 2.28 & 2.32 & 2.37 & 2.41 & 2.44 & & & & & \\
\hline OLG-5 & 2640 & 3.00 & 3.03 & 3.05 & 3.07 & 3.08 & 3.14 & 3.20 & 3.24 & & \\
\hline OLG-6 & 2660 & 3.02 & 3.04 & 3.06 & 3.08 & 3.10 & & & & & \\
\hline OLG-8 & 2610 & 2.58 & 2.64 & 2.67 & 2.69 & 2.71 & 2.78 & 2.86 & 2.91 & & \\
\hline OLG-10 & 2580 & 2.79 & 2.83 & 2.86 & 2.87 & 2.88 & & & & & \\
\hline OLG-12 & 2843 & 2.75 & 2.94 & 3.05 & 3.12 & 3.16 & 3.25 & 3.30 & 3.33 & 3.35 & 3.37 \\
\hline Aver. & 2636 & 2.74 & 2.80 & 2.84 & 2.87 & 2.90 & 3.06 & 3.12 & 3.16 & 3.35 & 3.37 \\
\hline
\end{tabular}

Table 11. Laboratory derived Vp/Vs ratios for Olympic greywackes

\begin{tabular}{|c|c|c|c|c|c|c|c|c|c|c|c|}
\hline \multicolumn{12}{|l|}{$\mathrm{Vp} / \mathrm{Vs}$} \\
\hline \multirow[t]{2}{*}{ Sample } & Density & \multicolumn{10}{|c|}{ Pressure $(\mathrm{MPa})$} \\
\hline & $\mathrm{kg} / \mathrm{m} 3$ & 20 & 40 & 60 & 80 & 100 & 200 & 400 & 600 & 800 & 1000 \\
\hline OLG-1 & 2480 & 1.77 & 1.77 & 1.75 & 1.73 & 1.72 & & & & & \\
\hline OLG-5 & 2640 & 1.80 & 1.82 & 1.83 & 1.83 & 1.83 & 1.84 & 1.86 & 1.86 & & \\
\hline OLG- 6 & 2660 & 1.75 & 1.75 & 1.75 & 1.75 & 1.74 & & & & & \\
\hline OLG-8 & 2610 & 1.93 & 1.89 & 1.88 & 1.87 & 1.87 & 1.85 & 1.87 & 1.90 & & \\
\hline OLG-10 & 2580 & 1.73 & 1.75 & 1.77 & 1.79 & 1.81 & & & & & \\
\hline
\end{tabular}


$\begin{array}{llllllllllll}\text { OLG-12 } & 2843 & 1.62 & 1.67 & 1.70 & 1.73 & 1.75 & 1.82 & 1.86 & 1.87 & 1.88 & 1.89\end{array}$

\begin{tabular}{llllllllllll} 
Aver. & 2636 & 1.77 & 1.77 & 1.78 & 1.78 & 1.79 & 1.84 & 1.86 & 1.88 & 1.88 & 1.89 \\
\hline
\end{tabular}

Table 12. Laboratory derived Poisson's ratios for Olympic greywackes

$(\sigma)$

\begin{tabular}{rccccccccccc}
\hline Sample & Density & \multicolumn{1}{c}{ Pressure (MPa) } \\
& $\mathrm{kg} / \mathrm{m} 3$ & 20 & 40 & 60 & 80 & 100 & 200 & 400 & 600 & 800 & 1000 \\
\hline OLG-1 & 2480 & 0.26 & 0.26 & 0.26 & 0.25 & 0.25 & & & & & \\
OLG-5 & 2640 & 0.28 & 0.28 & 0.29 & 0.29 & 0.29 & 0.29 & 0.30 & 0.30 & & \\
OLG-6 & 2660 & 0.26 & 0.26 & 0.26 & 0.26 & 0.25 & & & & & \\
OLG-8 & 2610 & 0.32 & 0.31 & 0.30 & 0.30 & 0.30 & 0.29 & 0.30 & 0.31 & & \\
OLG-10 & 2580 & 0.25 & 0.26 & 0.27 & 0.27 & 0.28 & & & & & \\
OLG-12 & 2843 & 0.20 & 0.22 & 0.24 & 0.25 & 0.26 & 0.29 & 0.30 & 0.30 & 0.30 & 0.31 \\
Aver. & 2636 & 0.26 & 0.26 & 0.27 & 0.27 & 0.27 & 0.29 & 0.30 & 0.30 & 0.30 & 0.31 \\
\hline
\end{tabular}

Table 13. Average Formation sonic velocities and densities.

\begin{tabular}{lccc}
\hline Formation/Lithology & $\underline{30 .}$ & $\begin{array}{c}\text { Average } \\
\text { velocity } \\
(\mathrm{km} / \mathrm{s})\end{array}$ & $\begin{array}{c}\text { Average } \\
\text { density } \\
\left(\mathrm{kg} / \mathrm{m}^{3}\right)\end{array}$ \\
\hline Undiff. Quaternary and Quinault Fm. & 4 & 1.895 & 2173 \\
Quinault Fm. - undifferentiated & 4 & 2.196 & 2153 \\
Quinault Fm. - claystone member & 6 & 2.060 & 2172 \\
Quinault Fm. - sand/sandstone member & 7 & 2.045 & 2202 \\
Quinault Fm. - siltstone member & 3 & 2.315 & 2223 \\
Quinault Fm. - all units, all wells & 19 & 2.105 & 2194 \\
Montesano Fm. - all units, all wells & 9 & 2.250 & 2183 \\
Montesano Fm. - claystone member & 3 & 2.120 & 2188 \\
Montesano Fm. - sandstone member & 3 & 2.404 & 2230 \\
Montesano Fm. - siltstone member & 3 & 2.226 & 2132 \\
Hoh rock assemblage & 17 & 2.573 & 2376 \\
\hline
\end{tabular}

Table 14. Compressional-Wave Reflection Coefficients ${ }^{1}$

\begin{tabular}{lcc}
\hline Formation 1/Formation 2 & $\underline{\mathrm{Rpp}}$ & $\underline{\mathrm{Rpp}(\%)}$ \\
Montesano Fm./Hoh rock assemblage & 0.111 & 11.1 \\
Quinault Fm.*/Hoh rock assemblage & 0.139 & 13.9 \\
Undiff. Quat. \& Quinault Fm./Hoh rock assemb. & 0.195 & 19.5 \\
& & \\
Montesano Fm./Quinault Fm.* & 0.029 & 2.9 \\
Undiff. Quat. \& Quinault Fm./Montesano Fm. & 0.086 & 8.6 \\
Undiff. Quat. \& Quinault Fm./Quinault Fm. & 0.057 & 5.7 \\
\hline
\end{tabular}

\footnotetext{
${ }^{1}$ Rpp calculated from equation 1 .

*Used values for Quinault Fm. - all units, all wells.
} 


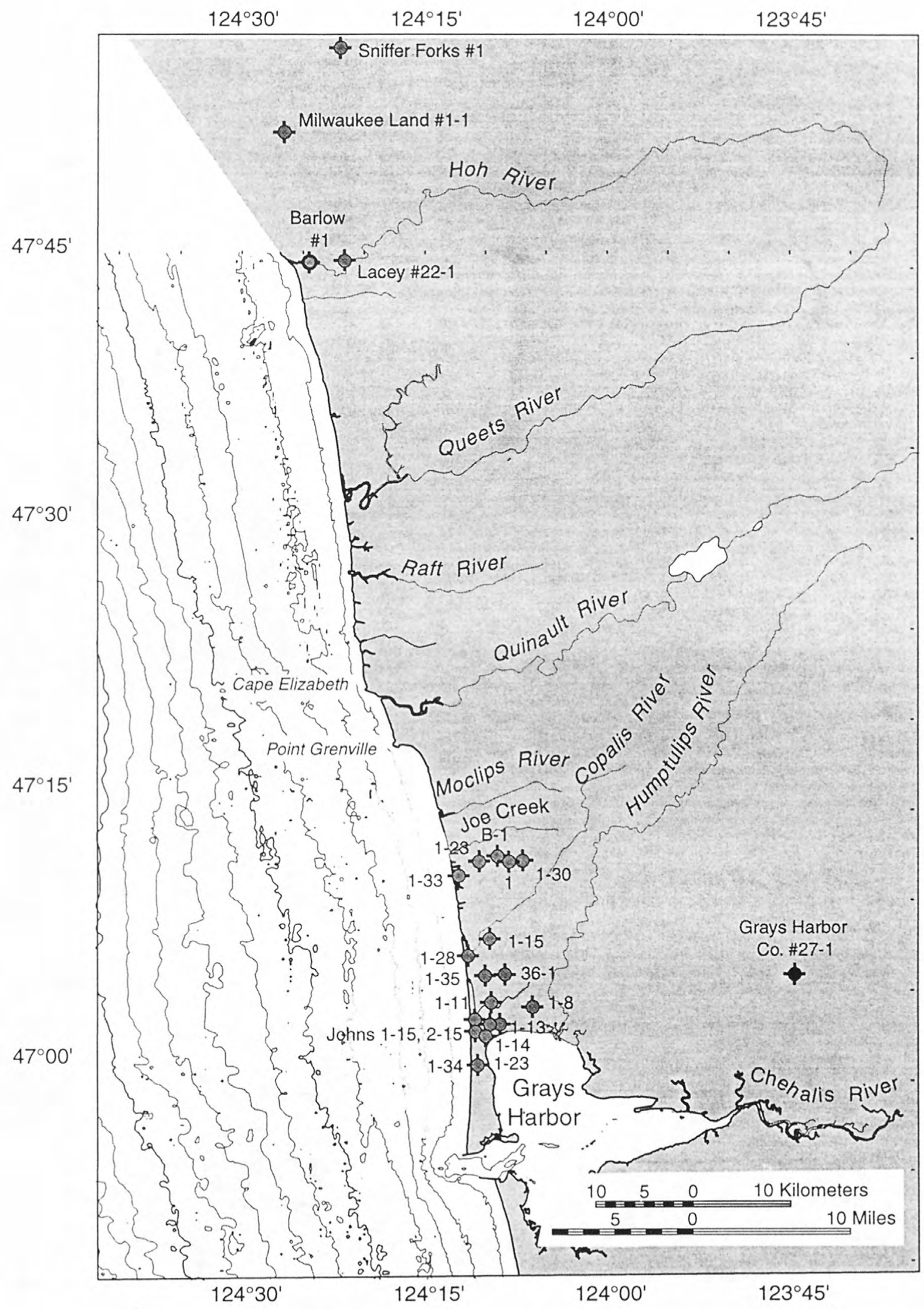

Figure 1. Map showing locations of oil test wells (circles with ticks) analyzed in this report. Bathymetric contours generated from NOAA-NOS hydrographic soundings. 
Shell, OCA Hogan \#1-13

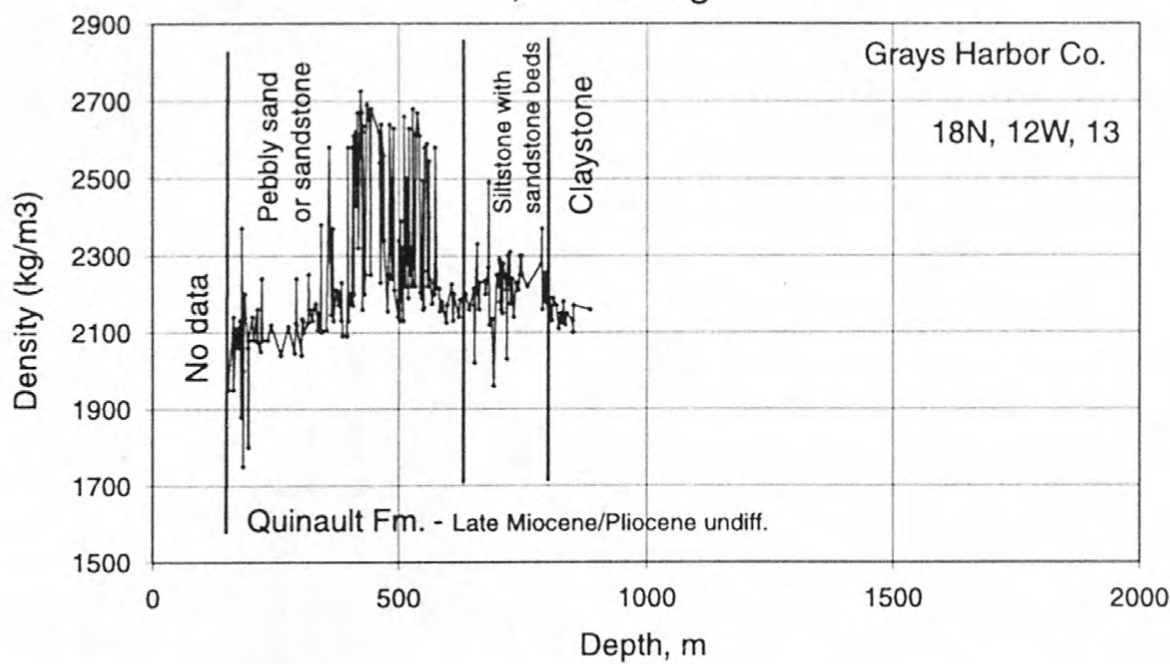

$\stackrel{N}{\sim}$

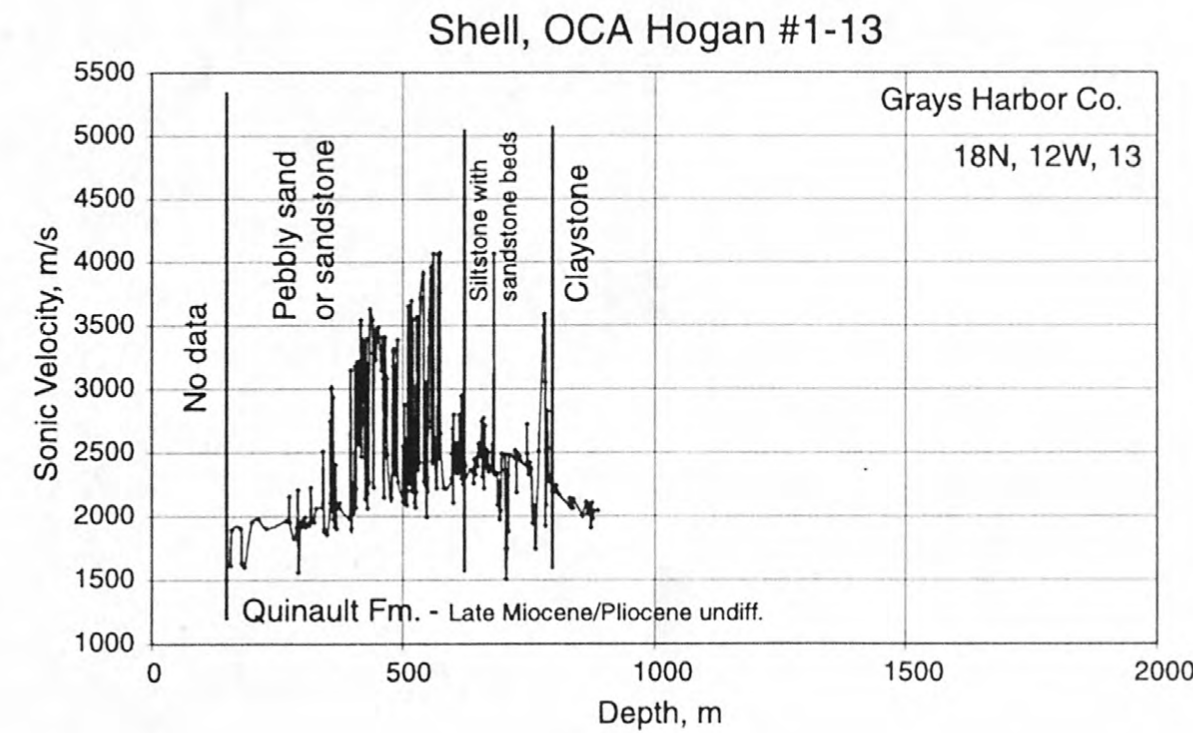

Shell, Hogan \#1-8

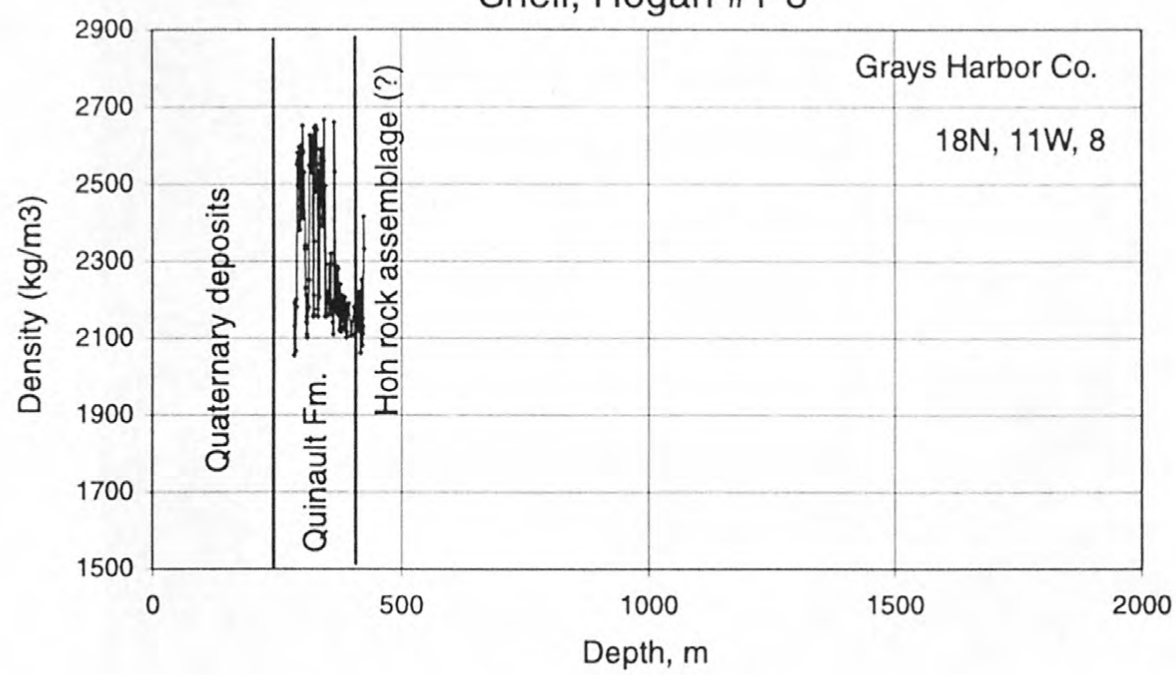

Shell, Hogan \#1-8

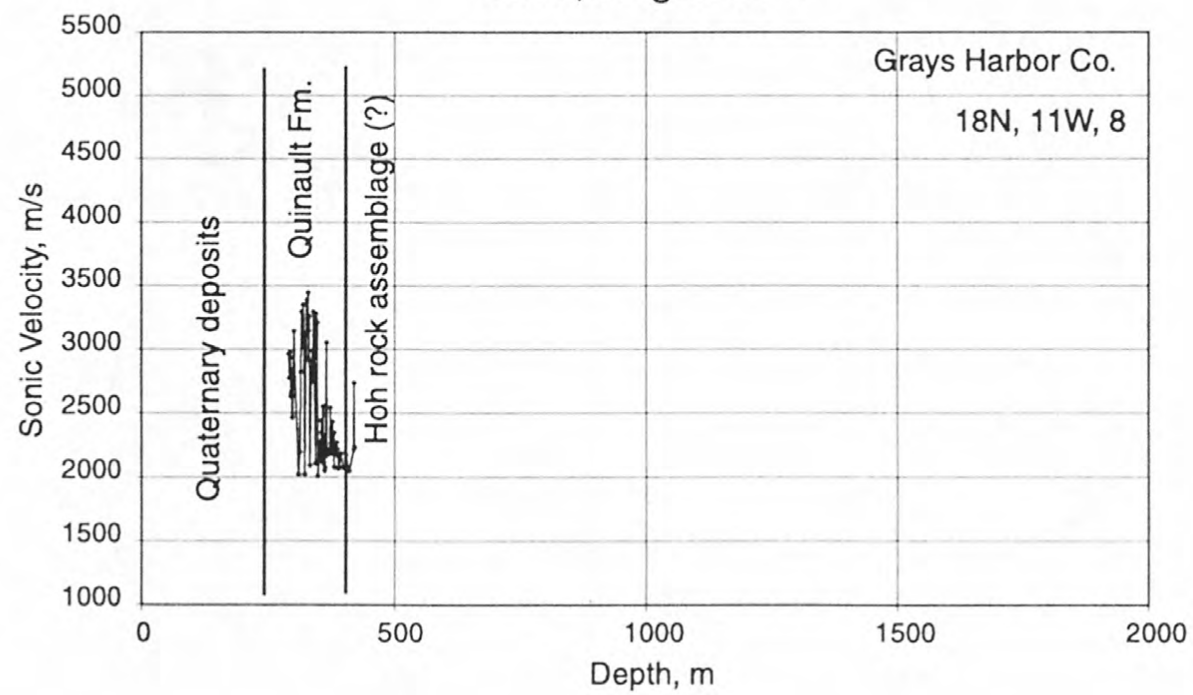

Figure 2. Sonic velocities and densities for the Shell Oil OCA Hogan 1-13 and Hogan 1-8 wells. 
Shell, Grays Harbor Co. OCA \#1-11
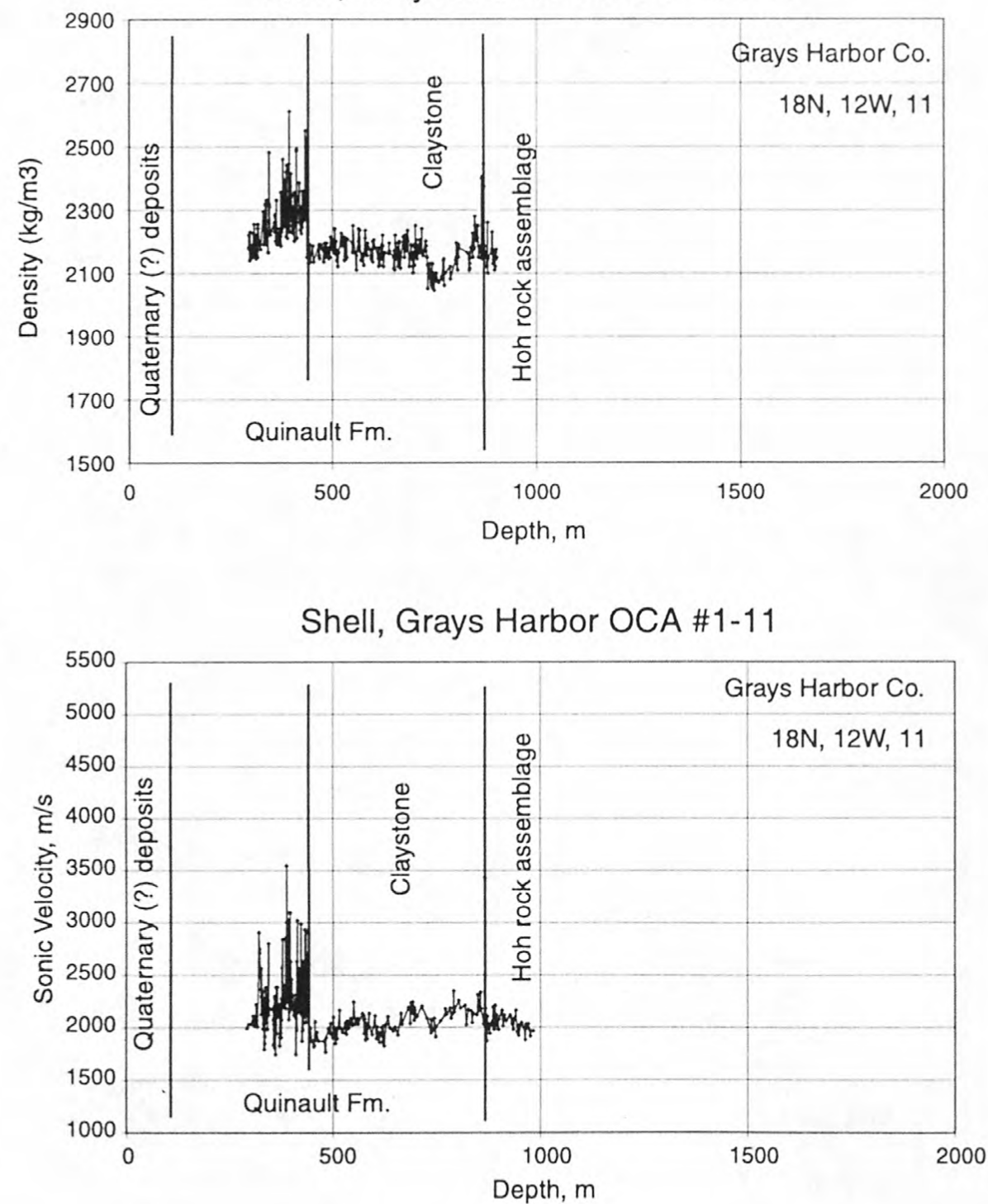

Shell, Ocean City Land Devel. Company \#1-14
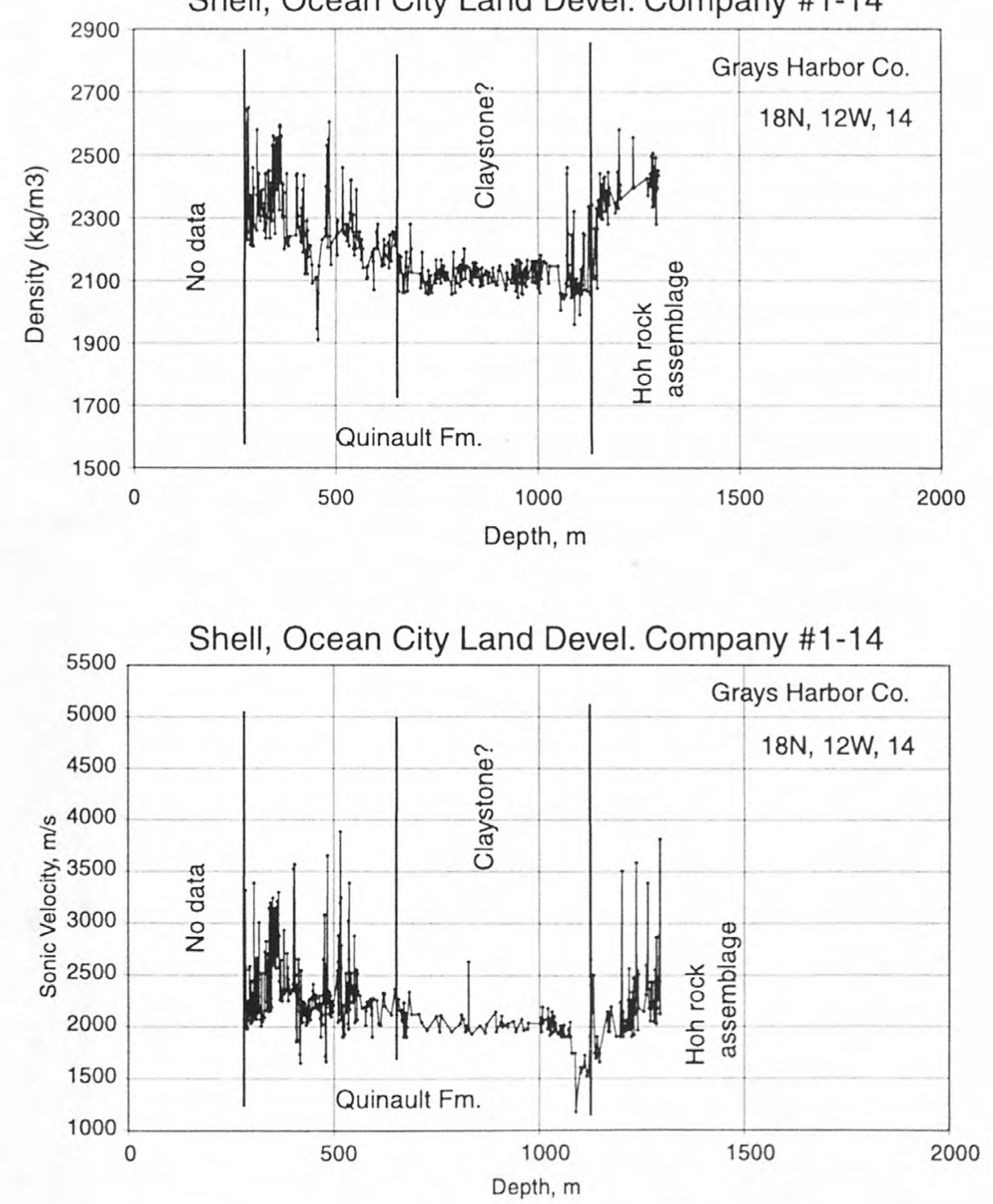

Figure 3. Sonic velocities and densities for the Shell Oil Grays Harbor County OCA 1-11 and Ocean City Land Development Co. 1-14 wells. 

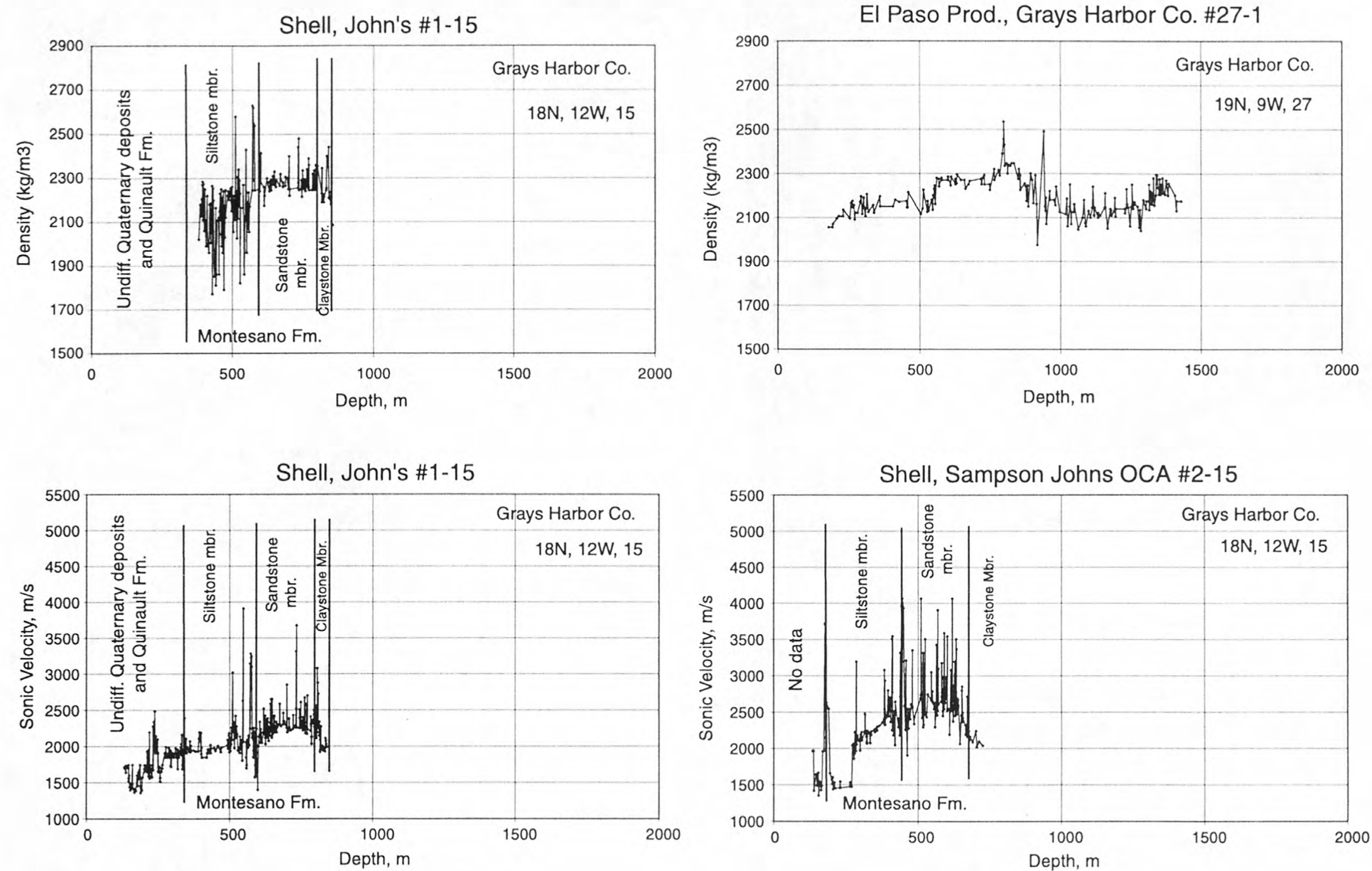

Figure 4. Sonic velocities and densities for the Shell Oil Johnson Sampson 1-15 and 2-15 and the El Paso Prod. Grays Harbor County 27-1 wells. 

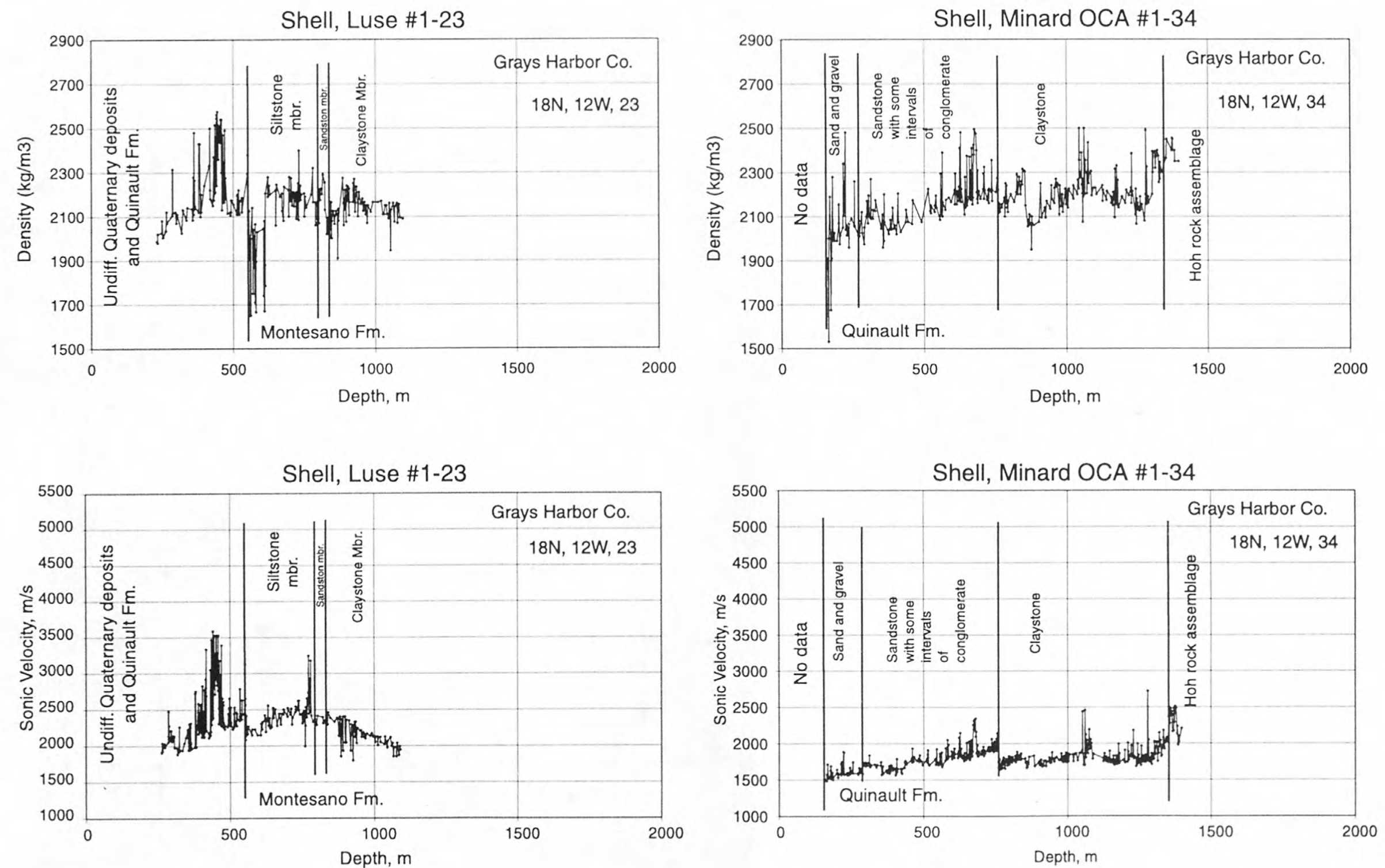

Figure 5. Sonic velocities and densities for the Shell Oil Luse 1-23 and Minard OCA 1-34 wells. 
Shell, Grays Harbor Co. LHA \#1-15

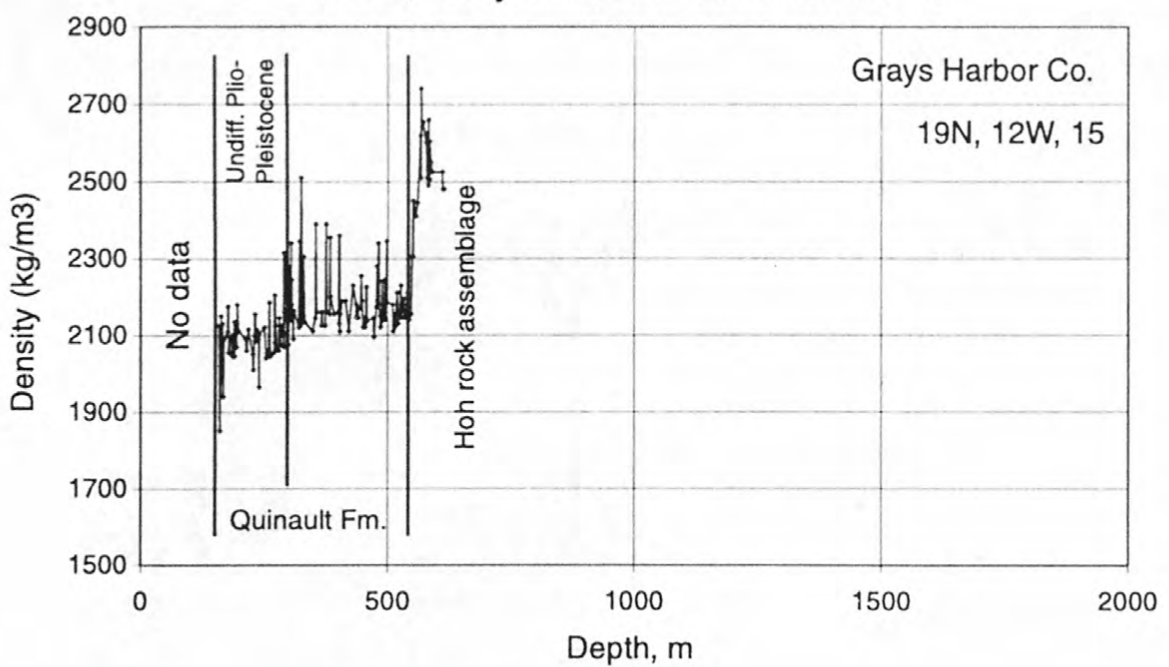

N

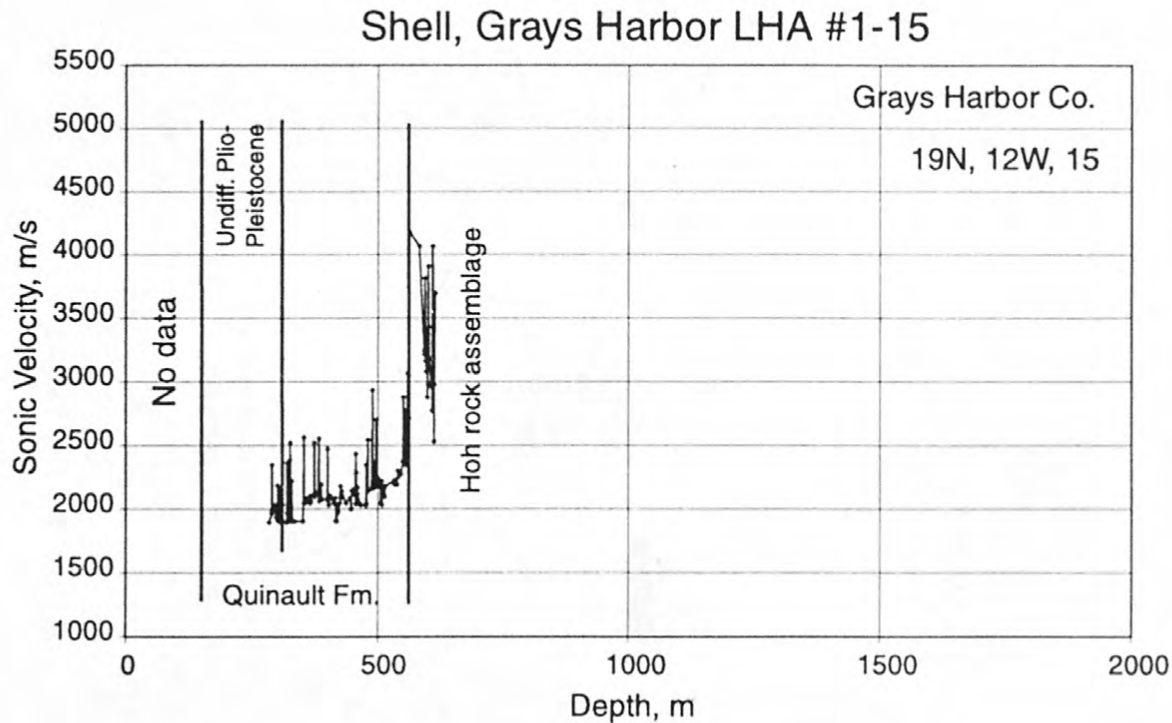

Shell, Trambitas OCA \#1-28
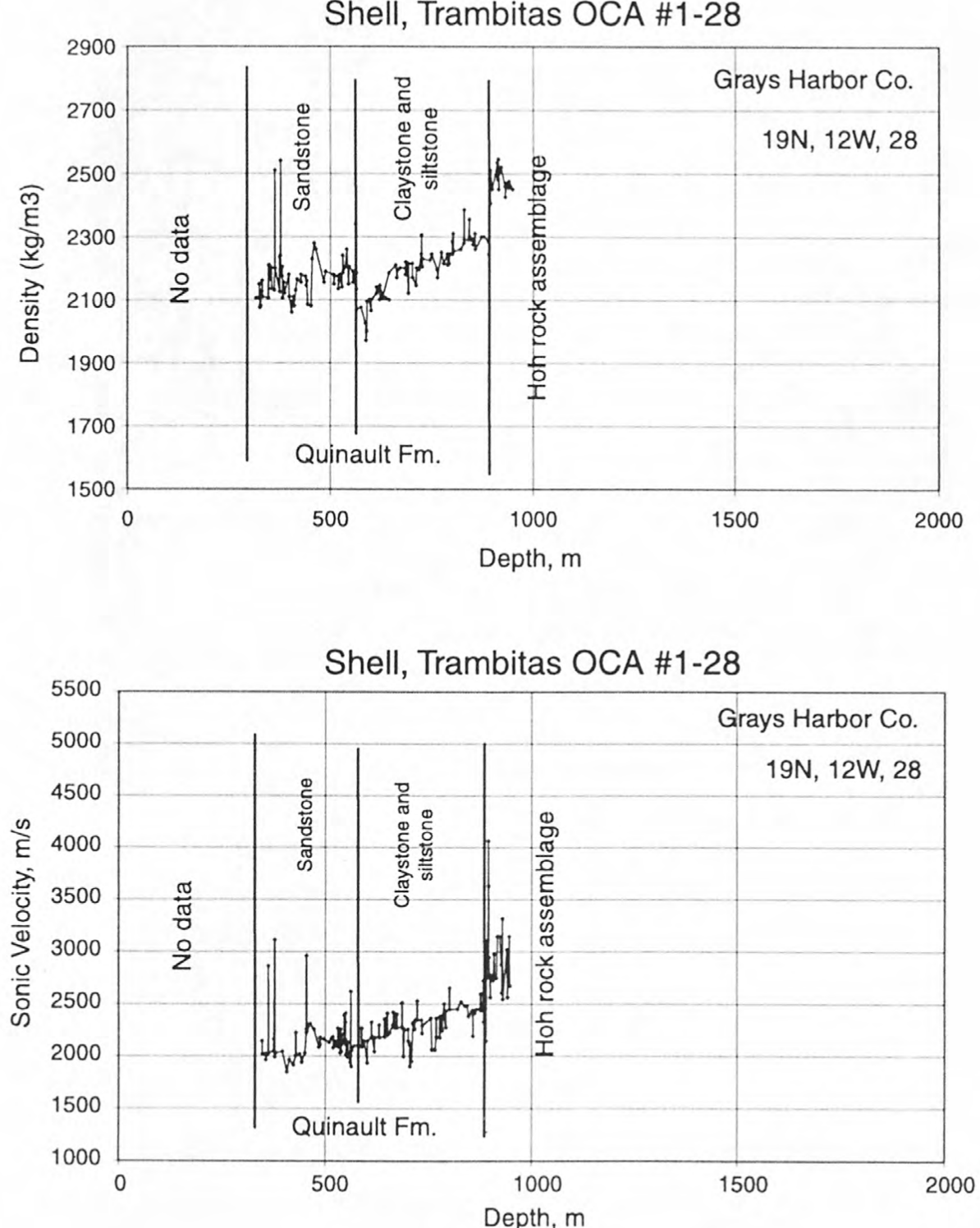

Figure 6. Sonic velocities and densities for the Shell Oil Grays Harbor County LHA 1-15 and Trambitas OCA 1-28 wells. 
Shell, Grays Harbor Co. \#1-35
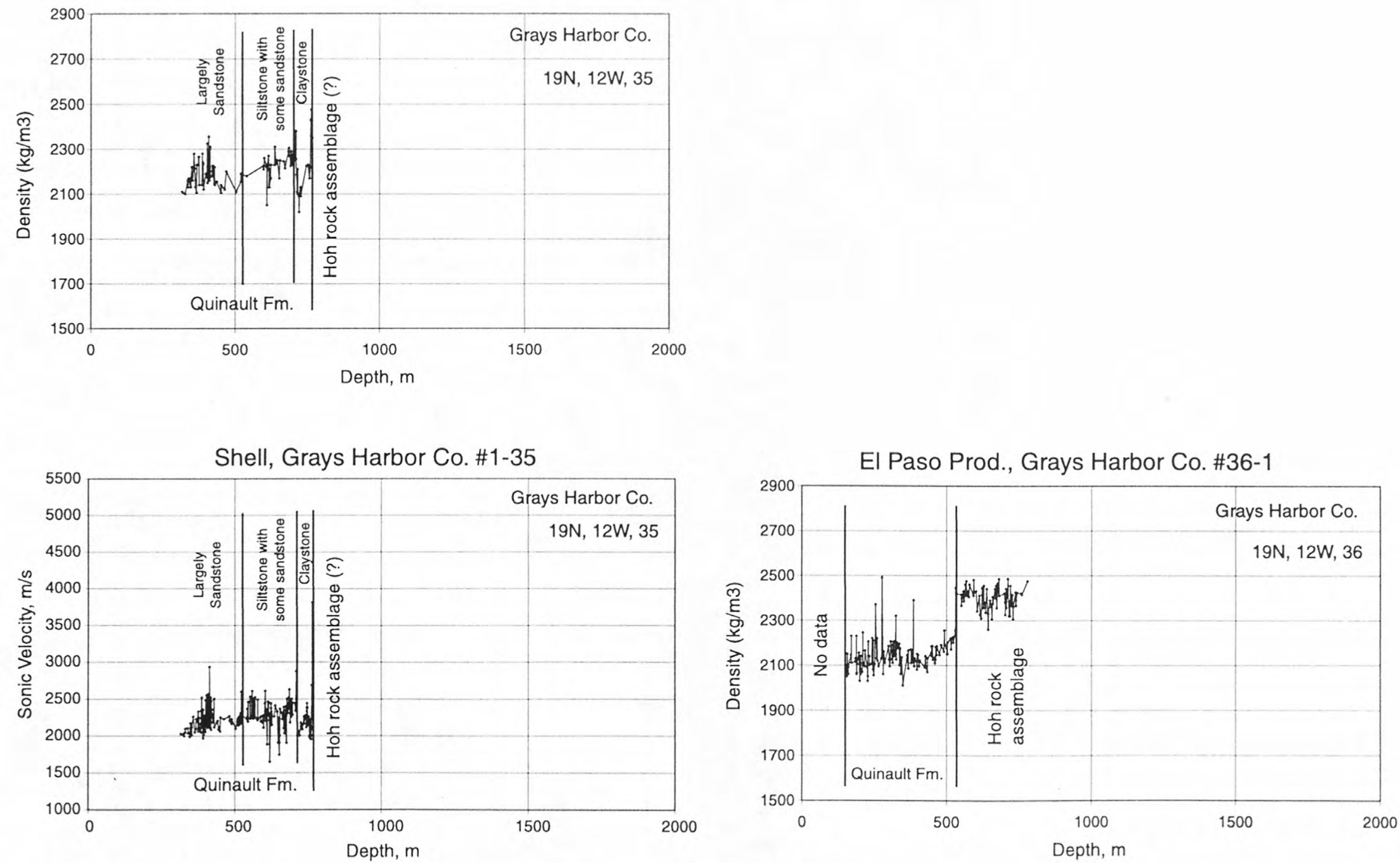

Figure 7. Sonic velocities and densities for the Shell Oil Grays Harbor County 1-35 and El Paso Prod., Grays Harbor County 36-1 wells. 

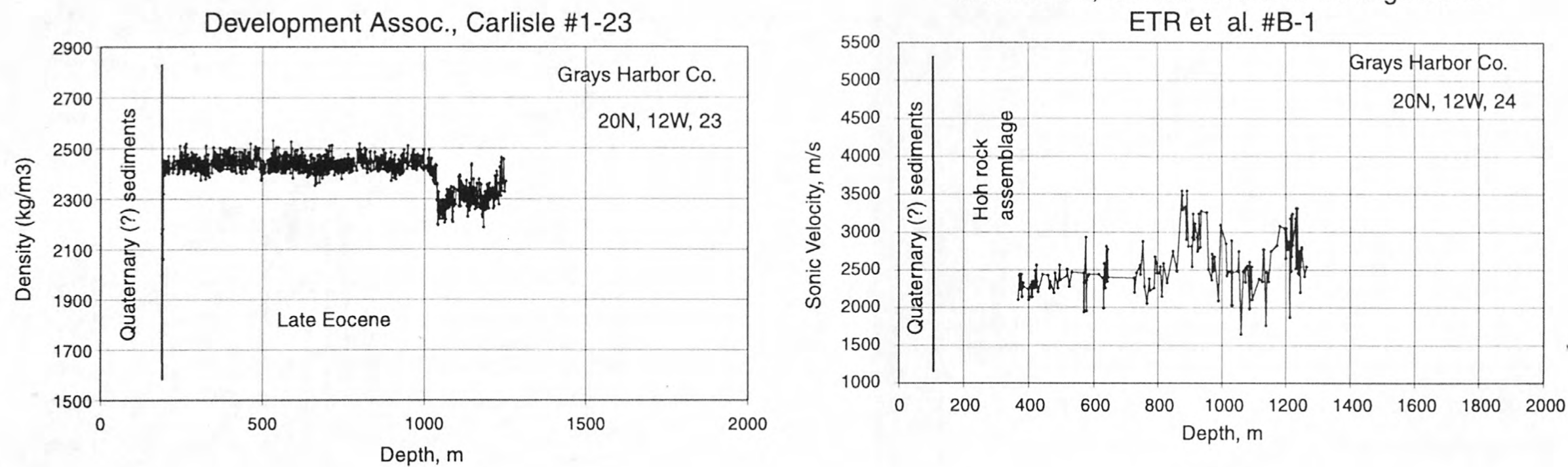

N

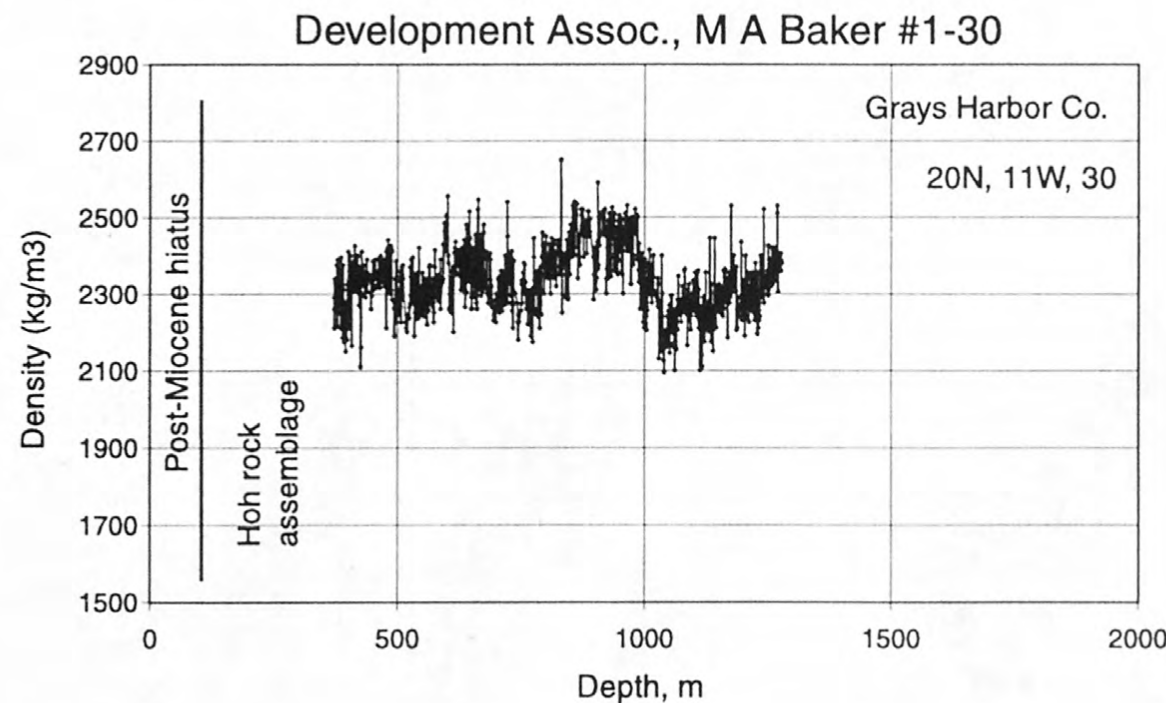

Figure 8. Sonic velocities and densities for the Development Assoc. M A Baker 1-20 and Carlisle 1-23 wells and Humble Oil Everett Trust and Savings Bank ETR et al. B-1 well. 


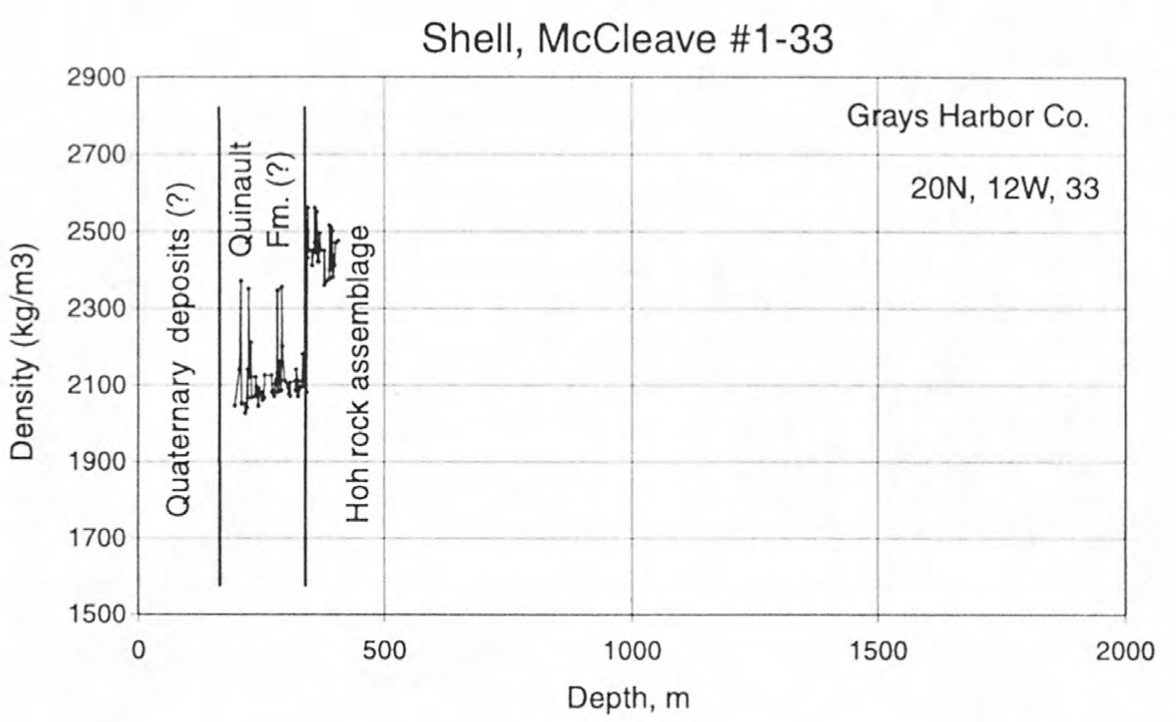

$\stackrel{N}{\infty}$

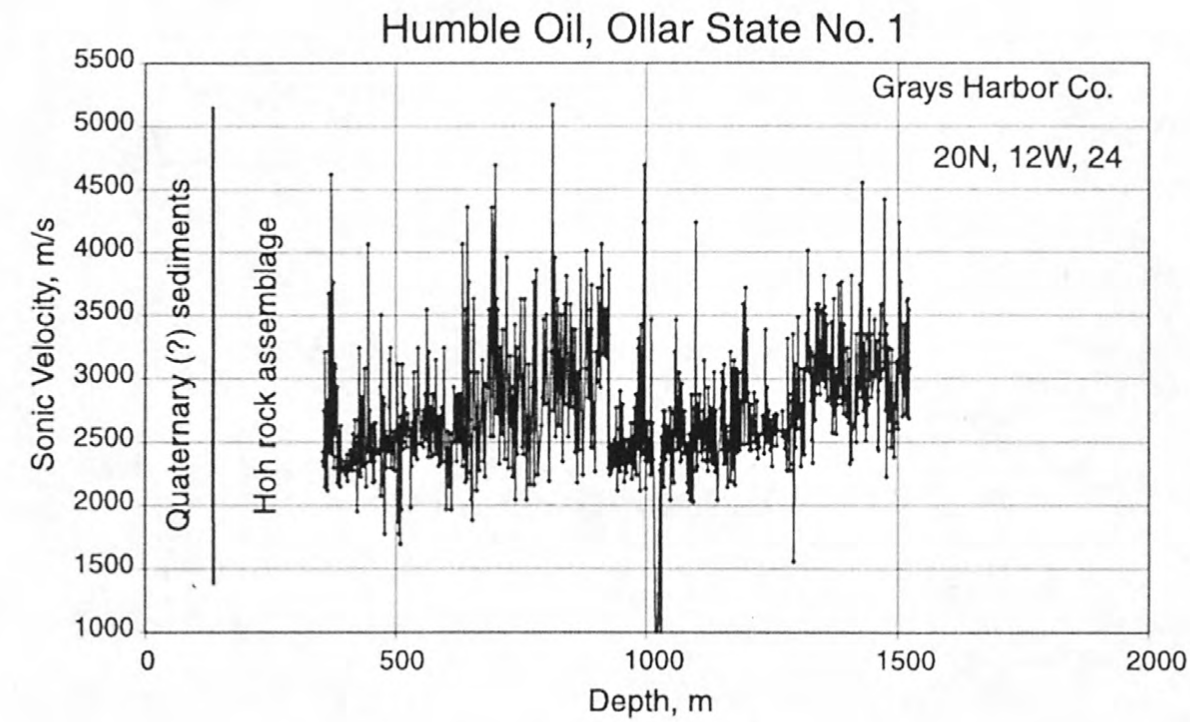

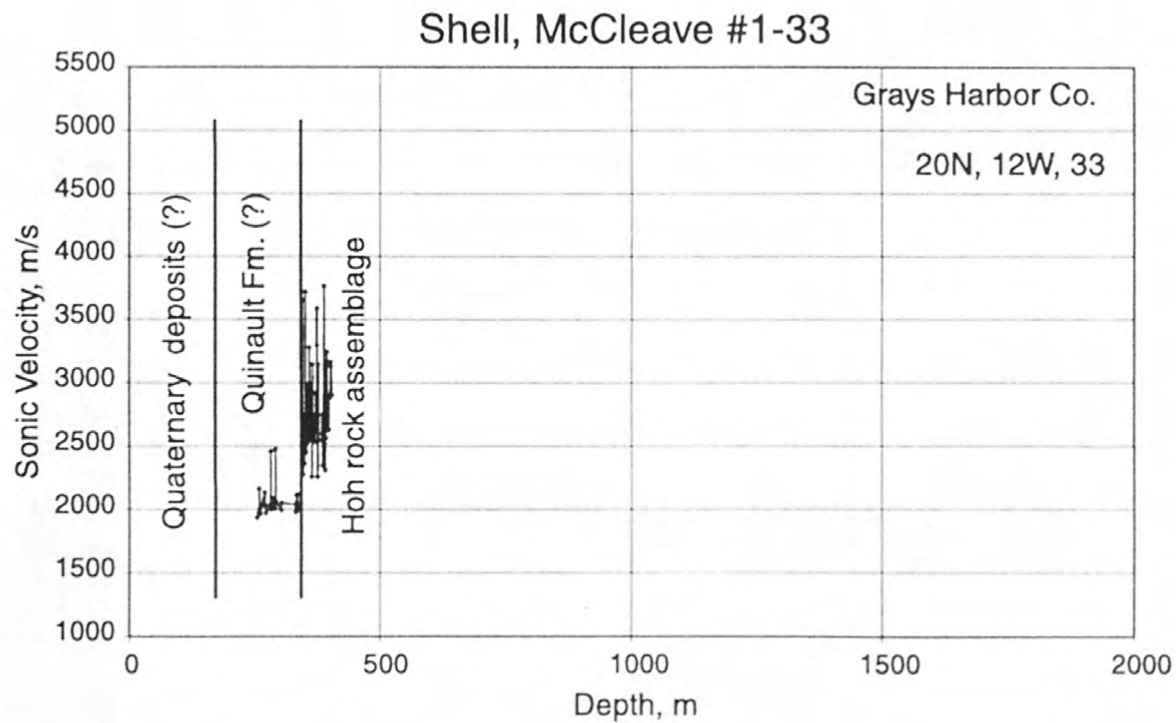

Figure 9. Sonic velocities and densities for the Humble Oil Ollar State 1 and Shell Oil McCleave 1-33 wells. 

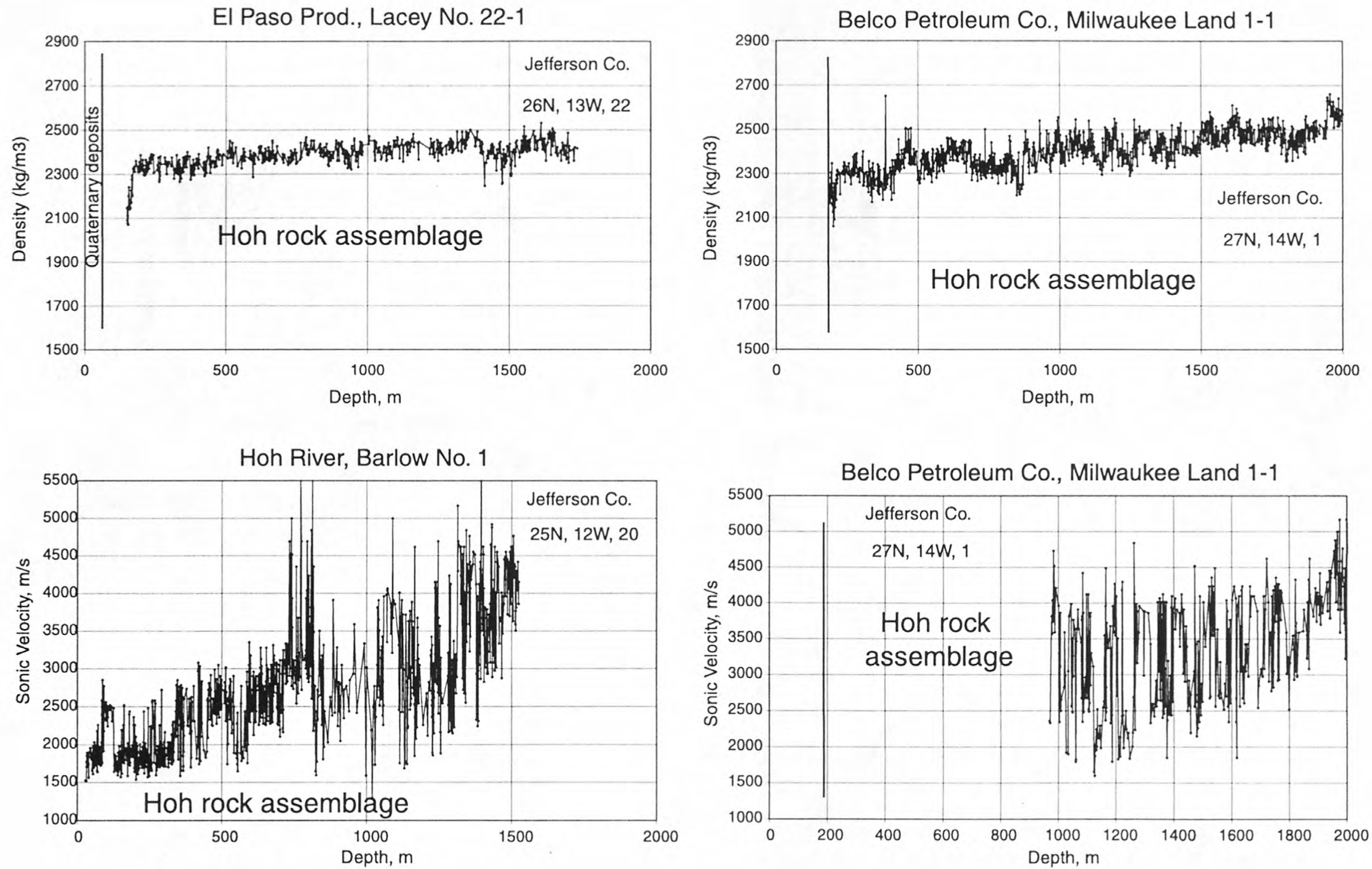

Figure 10. Sonic velocities and densities for the Hoh River Oil Barlow 1, El Paso Prod. Lacey 22-1, and Belco Petroleum Corp. Milwaukee Land 1-1 wells. 


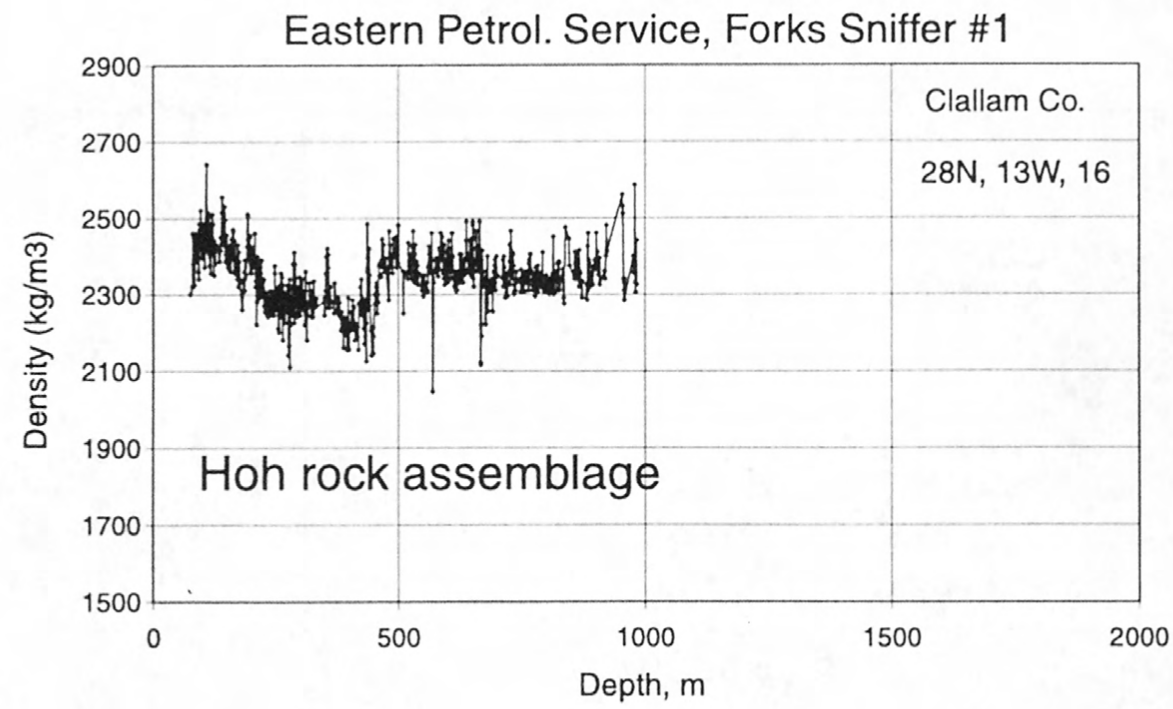

Figure 11. Densities for the Eastern Petroleum Services Sniffer Forks 1 well. 
Shell, Hogan \#1-8

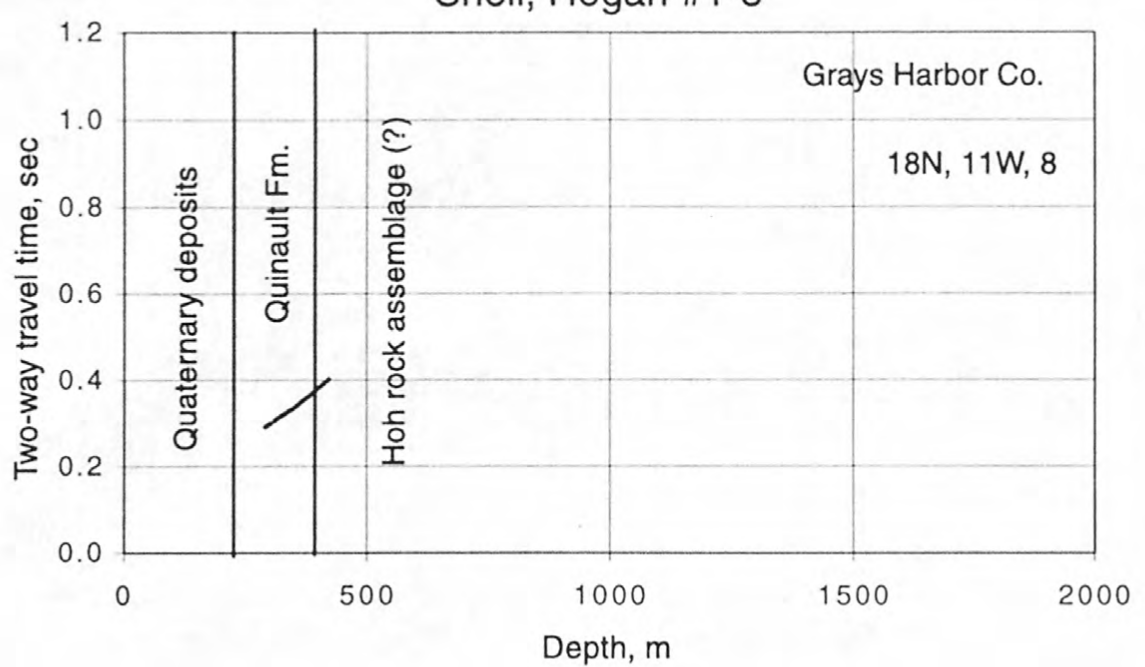

$\underline{\omega}$

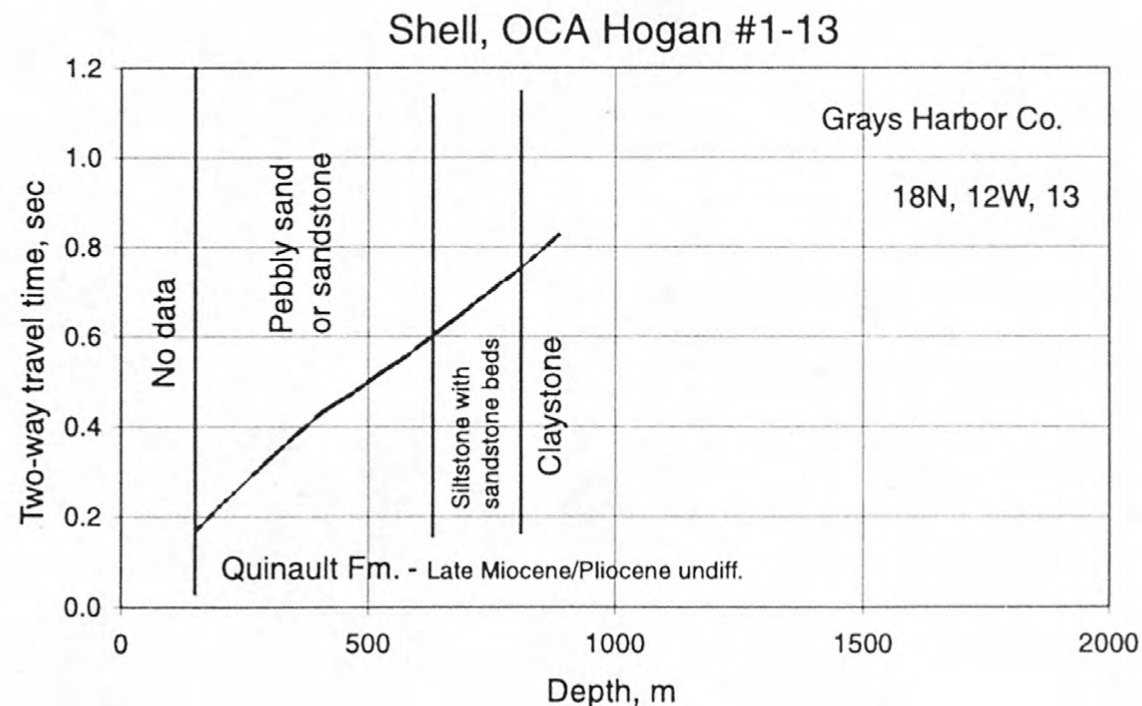

Shell, Ocean City Land Devel. Company \#1-14
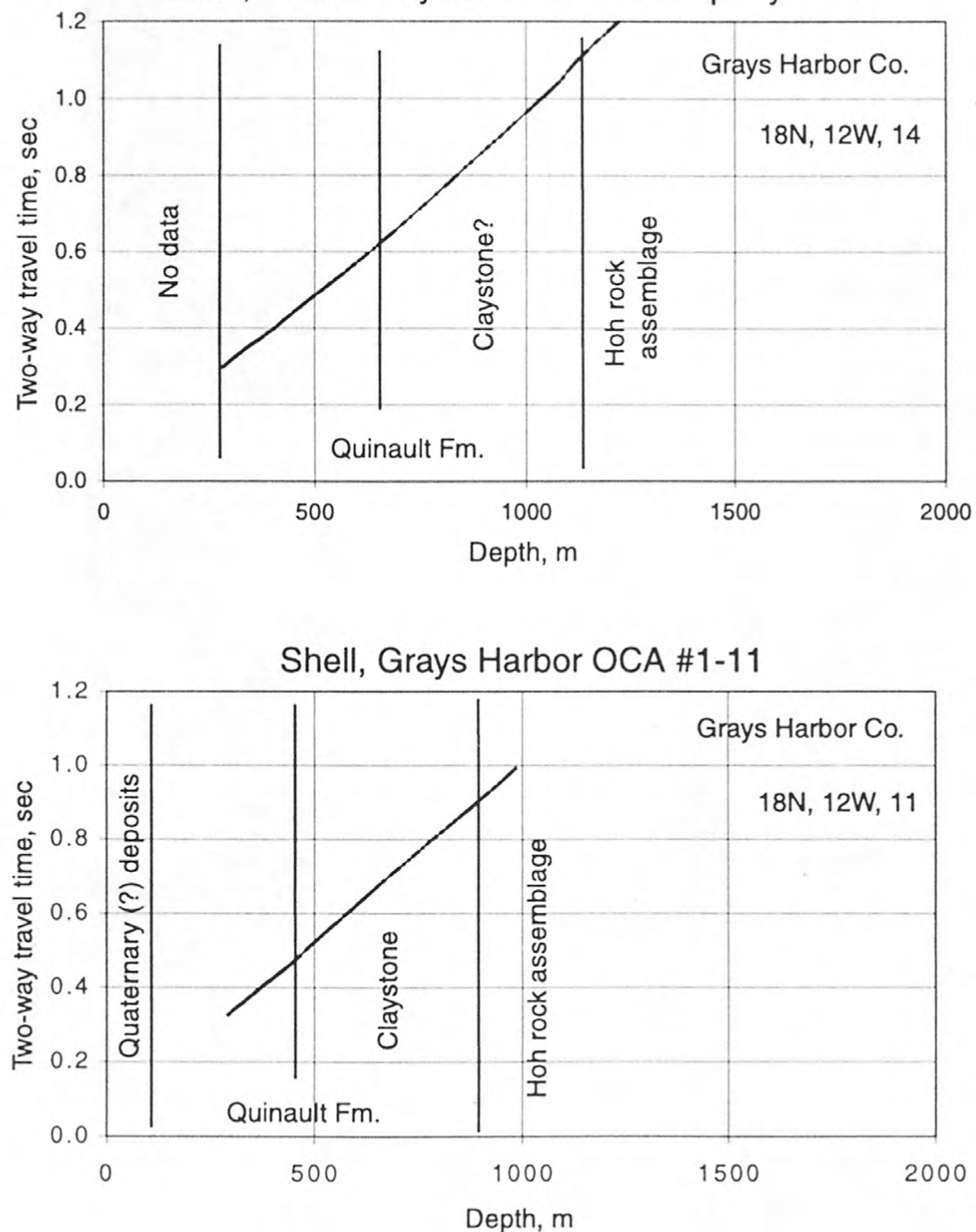

Figure 12. Calculated two-way travel times for the Shell Oil OCA Hogan 1-13, Hogan 1-8, Grays Harbor County 1-11, and Ocean City LDC $1-14$ wells. 
Shell, Sampson Johns OCA \#2-15

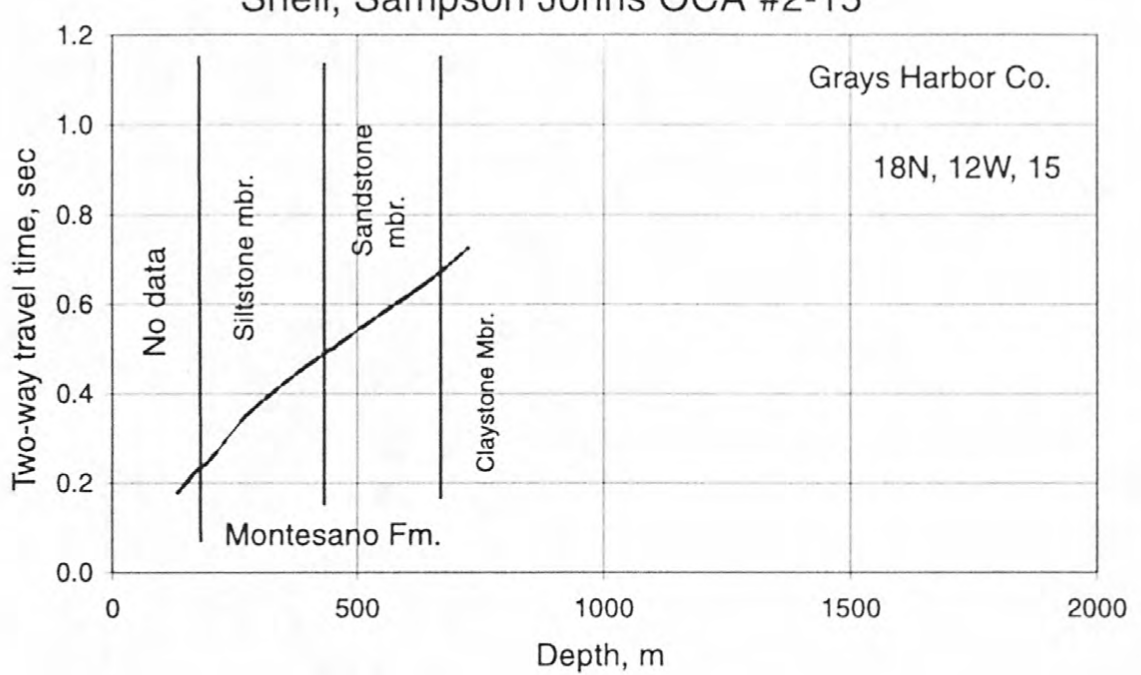

Shell, John's \#1-15

w

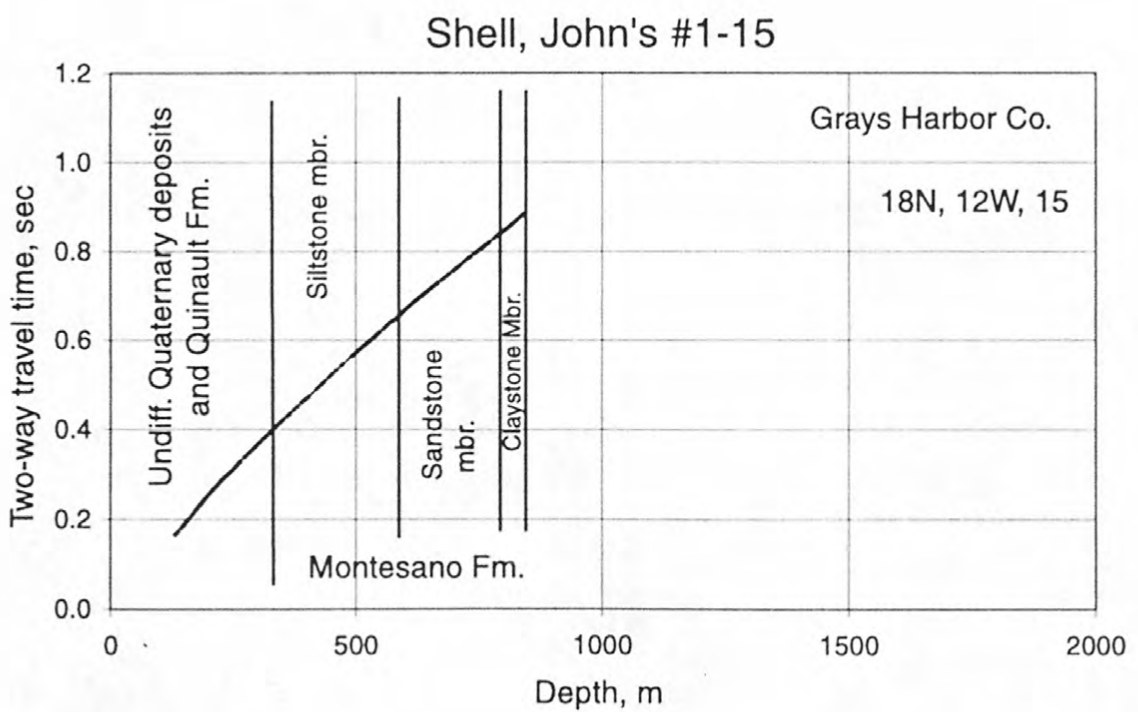

Shell, Minard OCA \#1-34

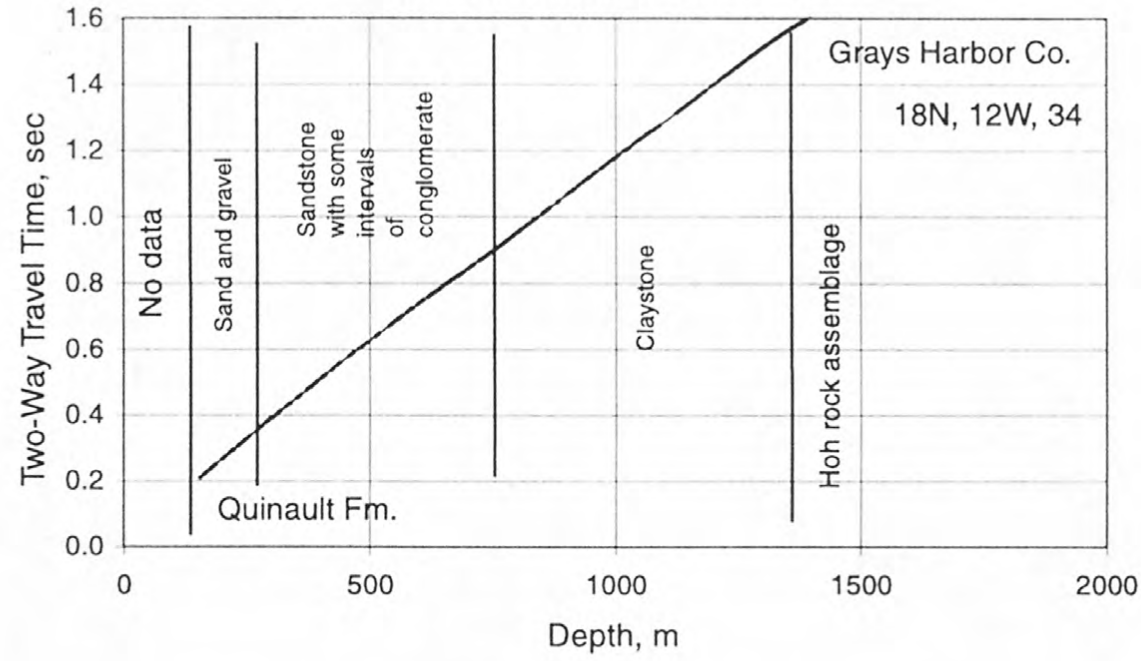

Shell, Luse \#1-23

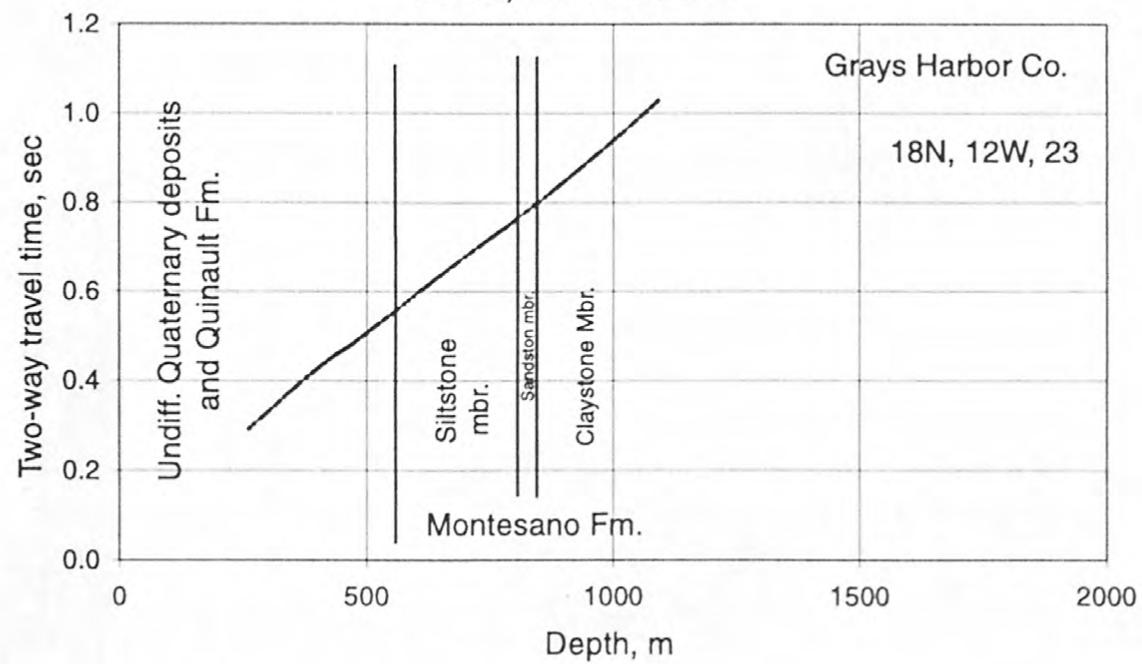

Figure 13. Calculated two-way travel times for the Shell Oil John Sampson 1-15, John Sampson OCA 2-15, Luse 1-23, and Minard OCA 1-34 wells. 

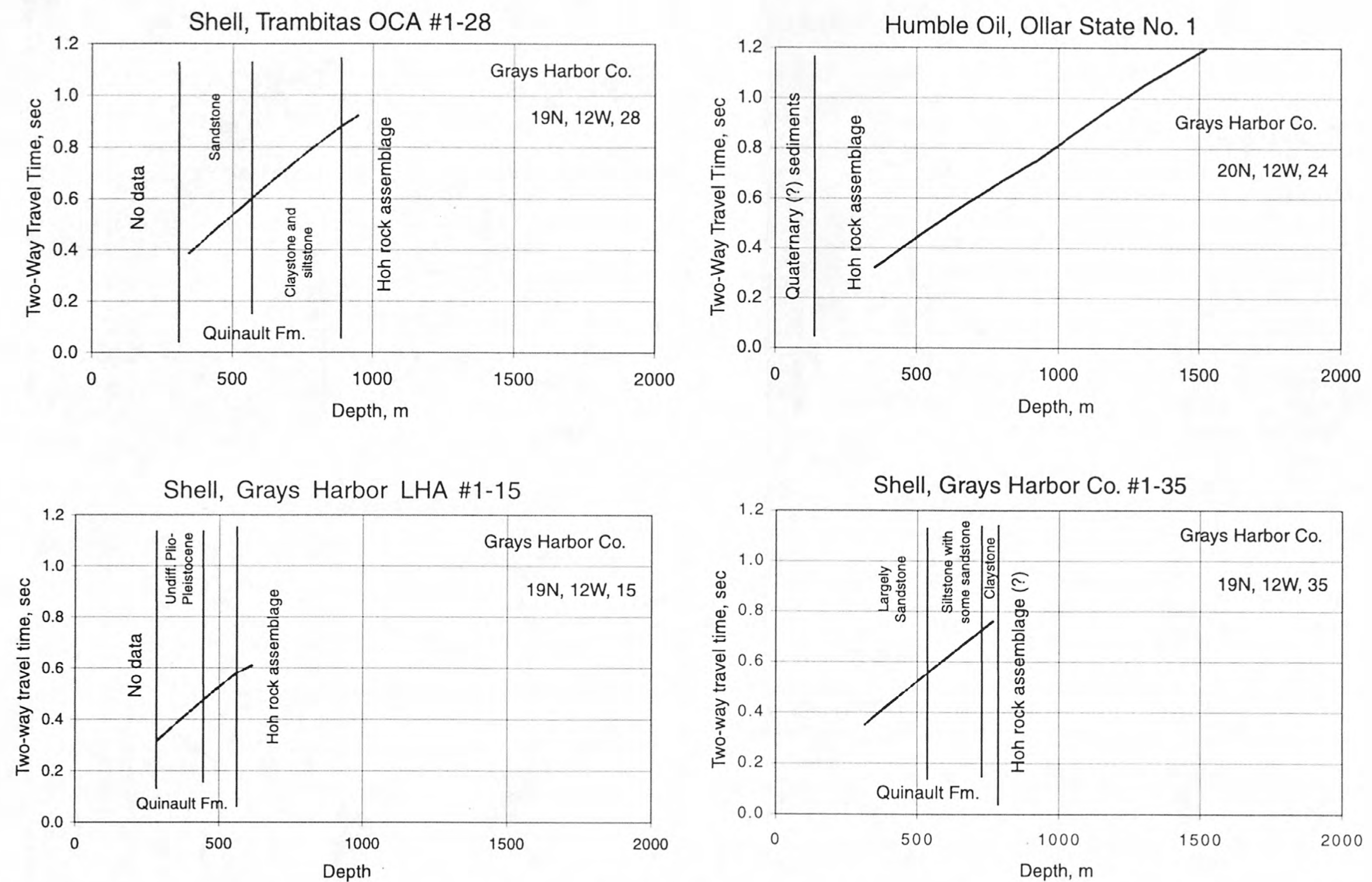

Figure 14. Calculated two-way travel times for the Shell Oil Grays Harbor County LHA 1-15, Trambitas OCA 1-28, Grays Harbor County 1-35, and Humble Oil Ollar State 1 wells. 

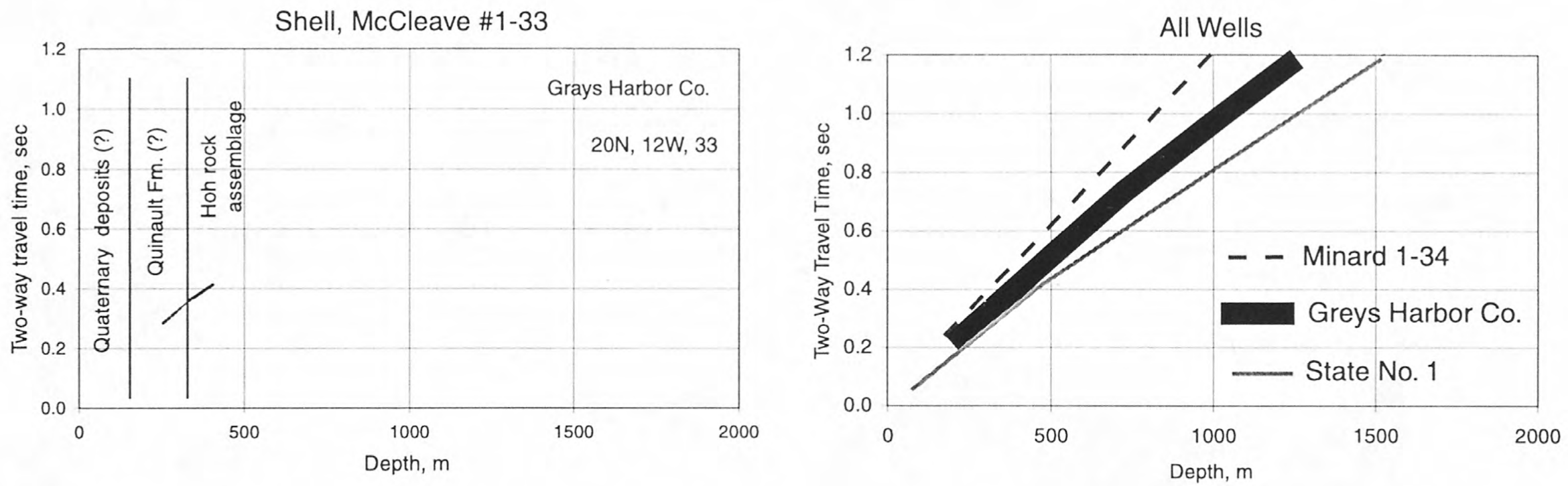

Humble Oil, Everett Trust and Savings Bank ETR et al. \#B-1
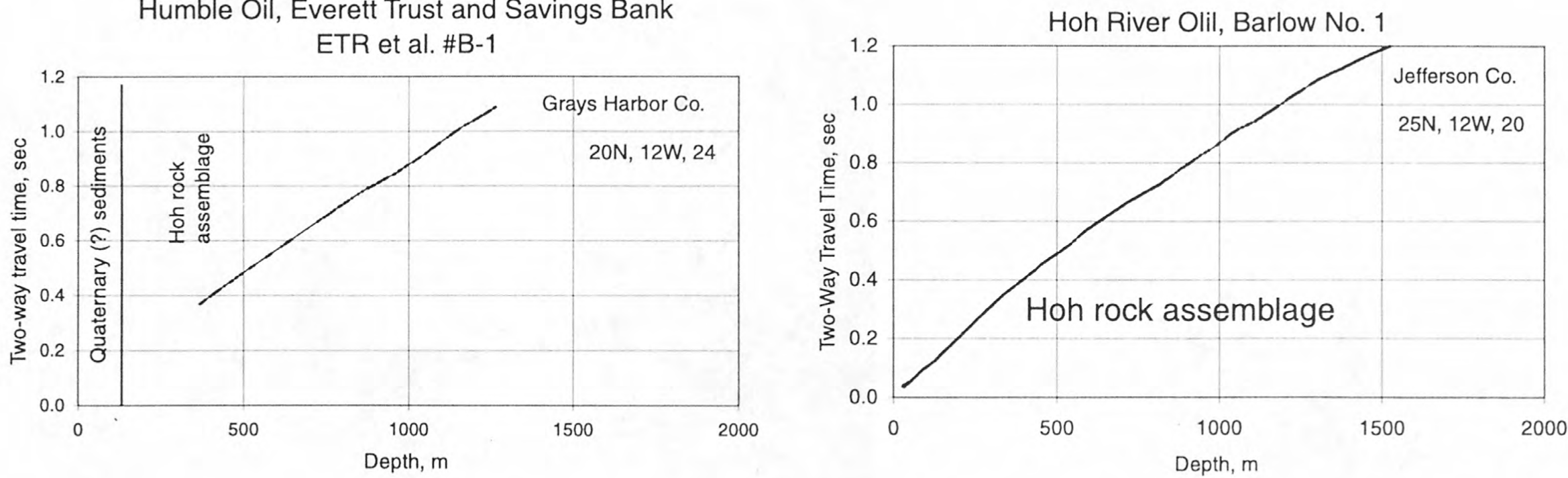

Figure 15. Calculated two-way travel times for the Humble Oil State B-1, Shell Oil McCleave 1-33, and Hoh River Oil Barlow 1 wells. Figure in upper right hand corner summarizes the calculated two way travel times for all the wells. 


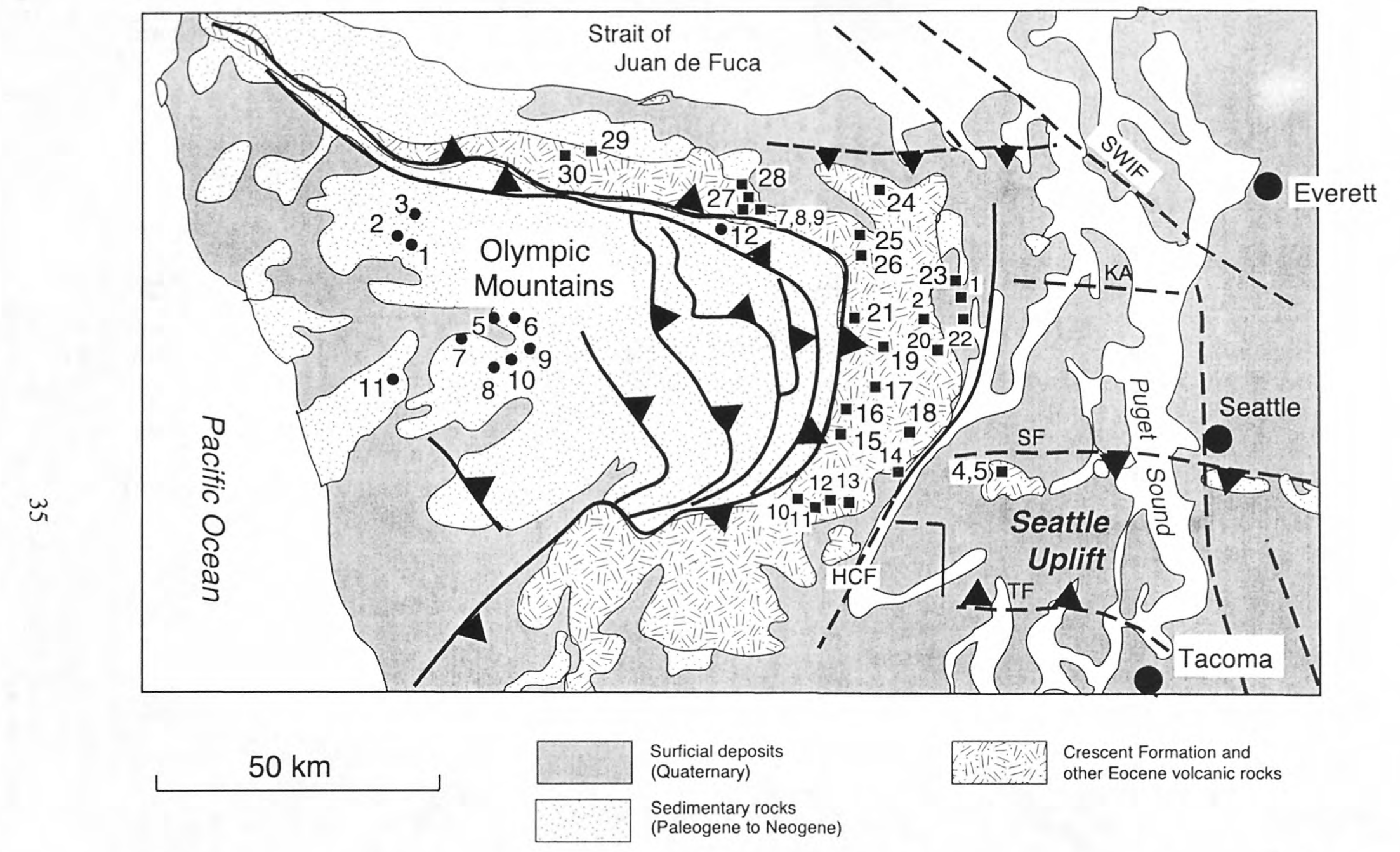

Figure 16. Map of the Olympic Peninsula showing the rock samples whose compressional and shear waves were measured in the laboratory. Abbreviations: HCF-Hood Canal fault, KA-Kingston Arch, SF-Seattle fault, TF-Tacoma fault. Figure modified from Brocher et al. (2001). 

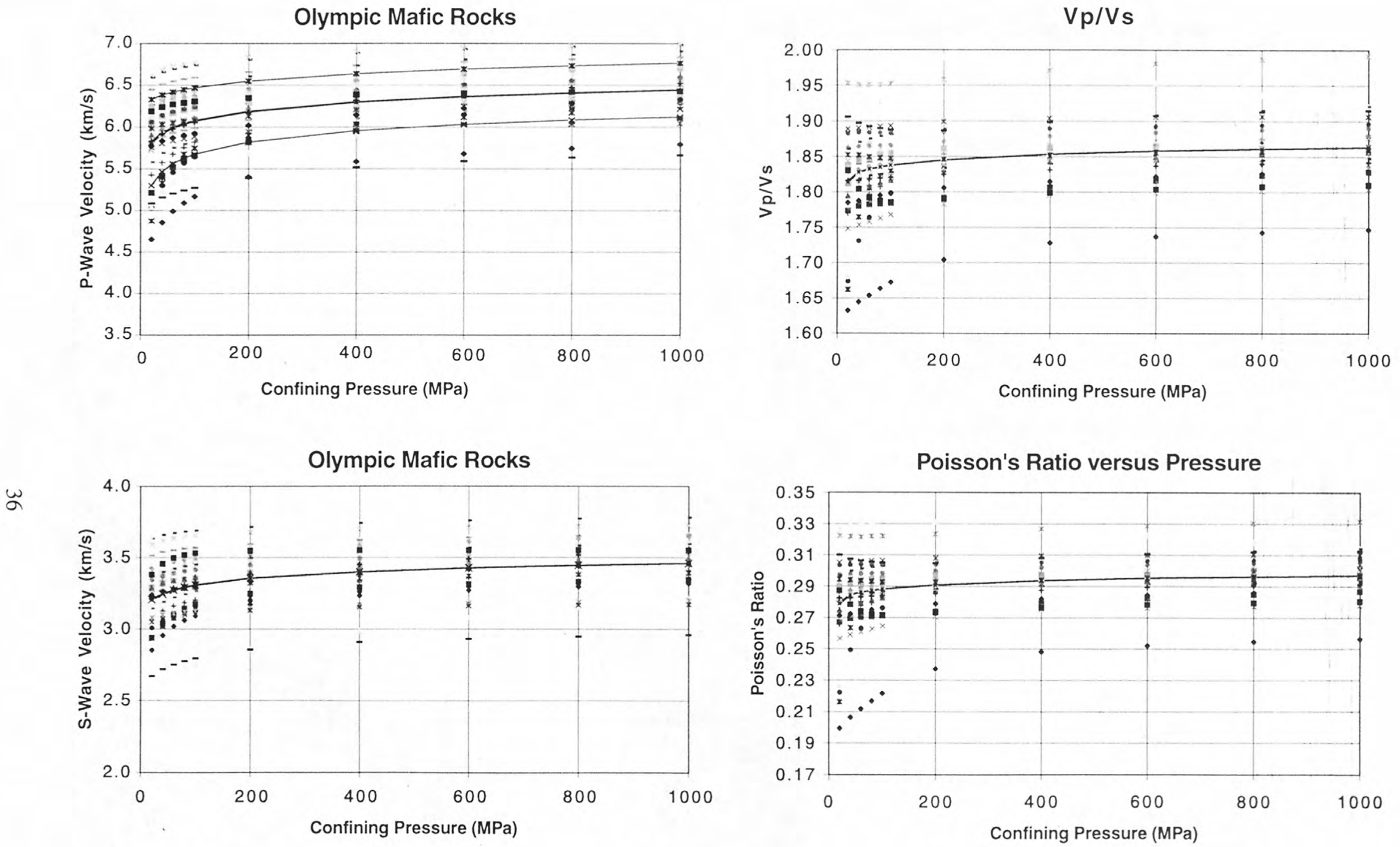

Figure 17. Compresional-wave, shear-wave, Vp/Vs ratio, and Poisson's ratio versus confining pressure for Olympic Peninsula mafic rocks (mainly Crescent Formation volcanics). 

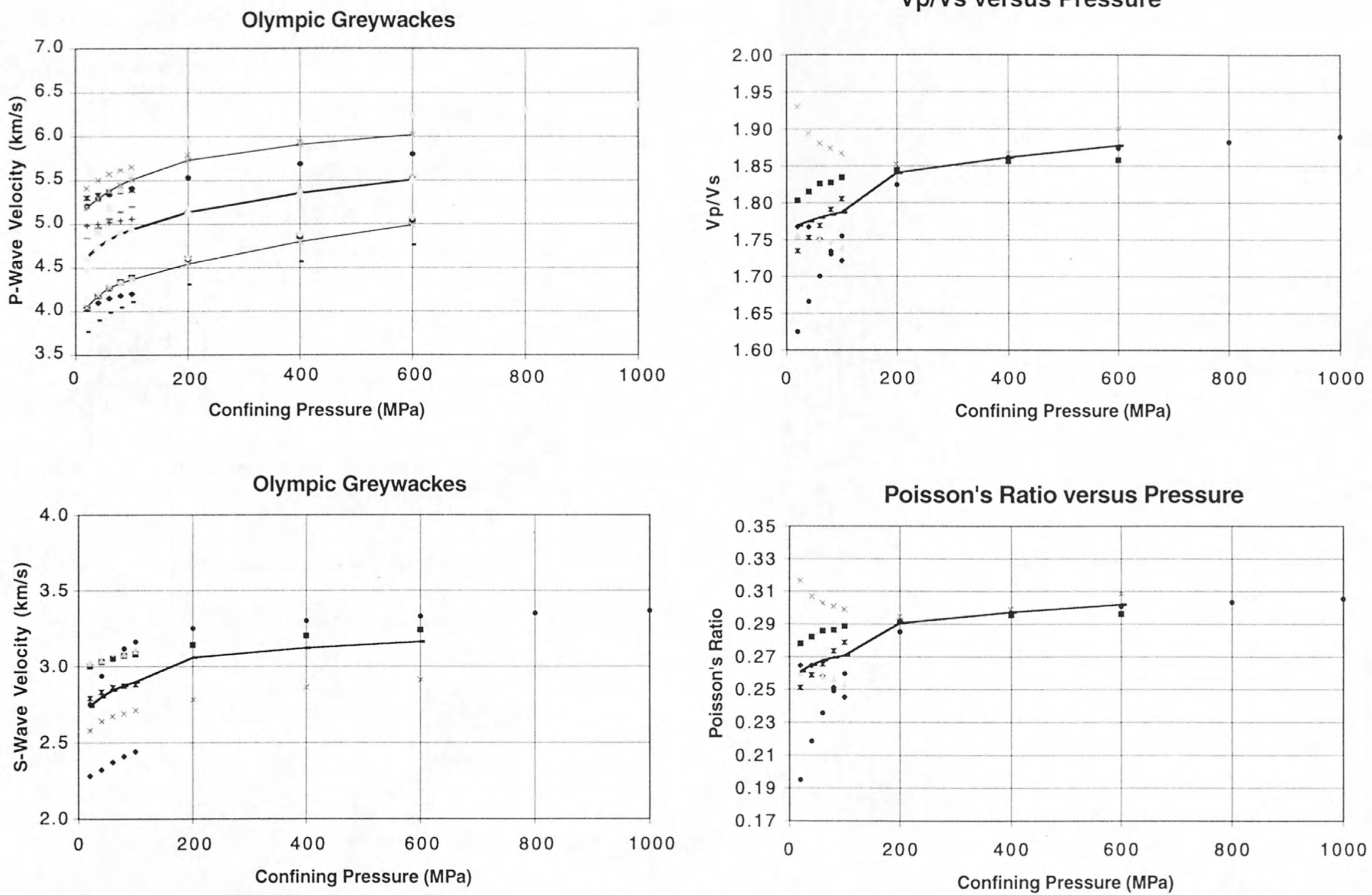

Figure 18. Compresional-wave, shear-wave, Vp/Vs ratio, and Poisson's ratio versus confining pressure for Olympic Peninsula greywackes. 

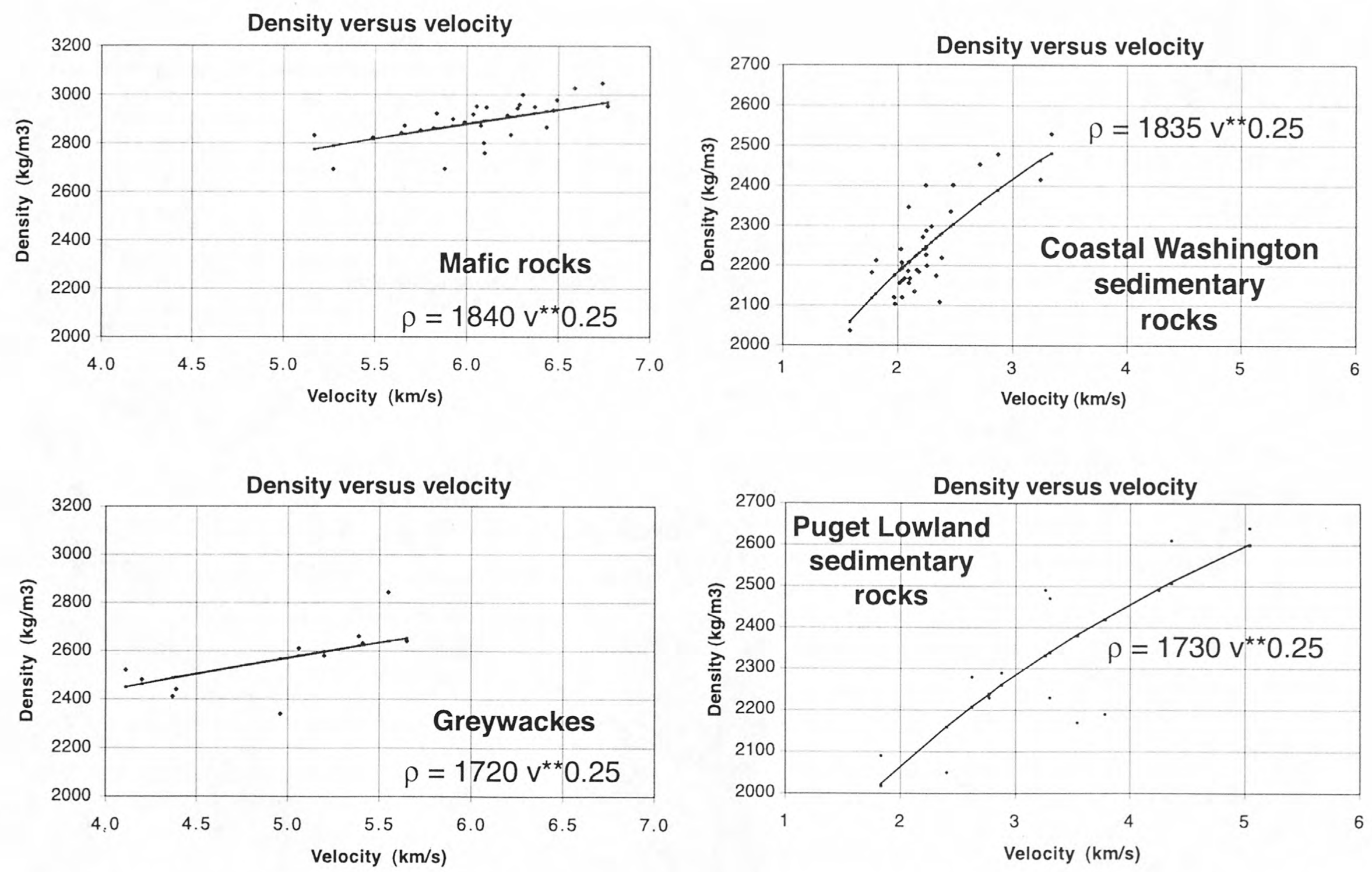

Figure 19. Density and velocity relationships for the Olympic Peninsula mafic and greywackes (left side), as well as for average sonic velocities and densities for the borehole logs presented here for coastal Washington, and for the Puget Lowland by Brocher and Ruebel (1998). 


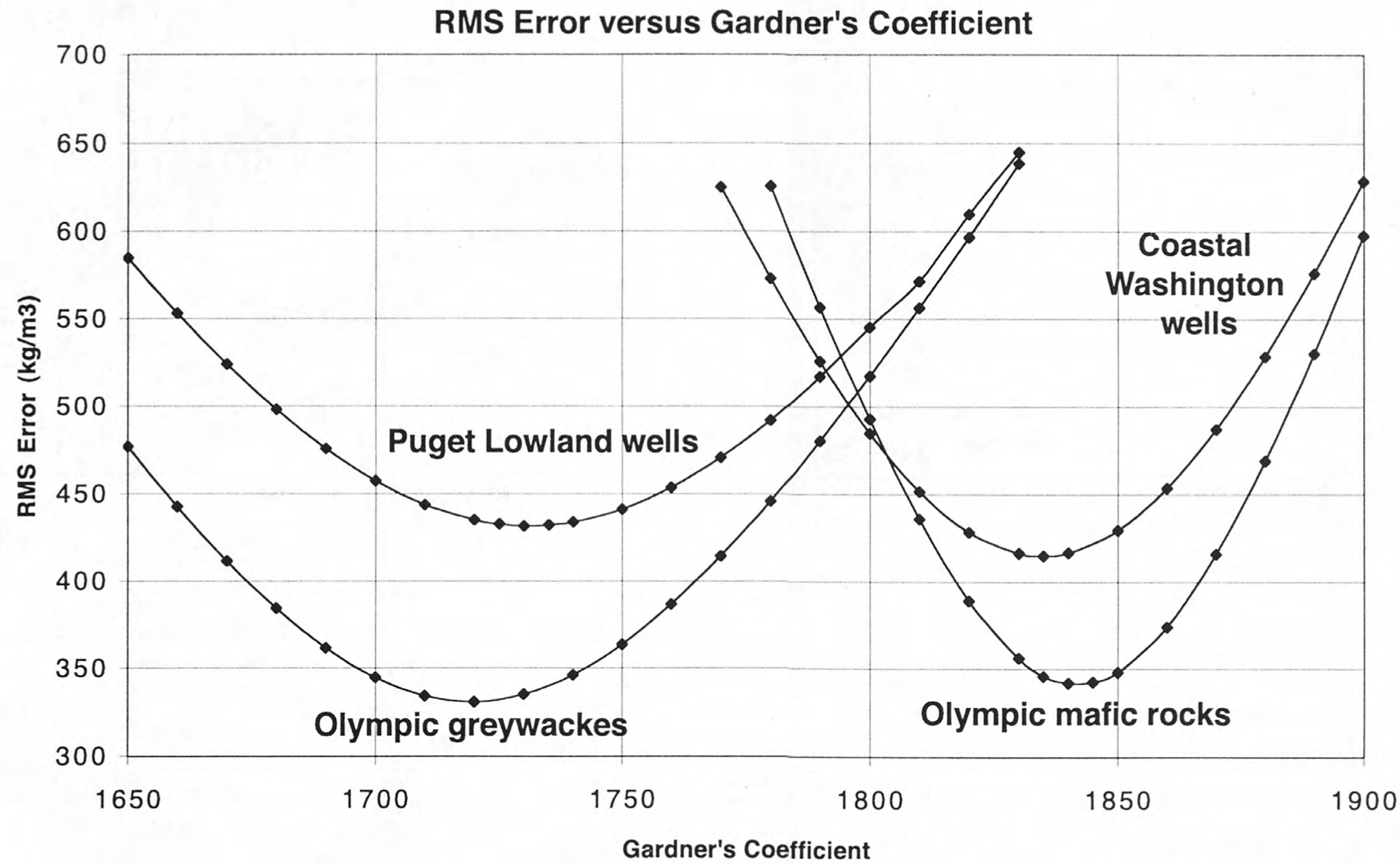

Figure 20. Graphs showing RMS misfit of the relationship $\rho=$ Gardner's coefficient $* v^{*} * 0.25$ for the various suites of rocks studied here and in Brocher and Ruebel (1998). 
